$$
\text { HAR VAR D B US INESS SCHOOL }
$$

\title{
Economic Transition and Private- Sector Labor Demand: Evidence from Urban China
}

Lakshmi Iyer

Nancy Qian
Xin Meng

Xiaoxue Zhao

Working Paper 14-047 


\section{Economic Transition and Private-Sector Labor Demand: Evidence from Urban China}

\section{Lakshmi Iyer}

Harvard Business School

Nancy Qian

Yale University
Xin Meng

Australian National University

Xiaoxue Zhao

Duke University

Working Paper 14-047 


\title{
Economic Transition and Private-Sector Labor
}

\section{Demand: Evidence from Urban China*}

\author{
Lakshmi Iyer’ Xin Meng; Nancy Qian§ Xiaoxue Zhao
}

March 2016

\begin{abstract}
This paper studies the policy determinants of economic transition and estimates the elasticity demand for labor in the infant private sector in urban China. We show that a reform that untied access to housing in urban areas from working for the state sector accounts for more than a quarter of the overall increase in labor supply to the private sector during 1986-2005. We do not find any increase in self-employment. Using the reform to instrument for privatesector labor supply, we find that private-sector labor demand is very elastic, with elasticity estimates ranging between -3.1 and -5.3 .
\end{abstract}

Keywords: Economic Transition, Structural Change, Labor Mobility.

JEL: O12, P2, P26, J23.

${ }^{*}$ We are grateful to two anonymous referees, Philipe Aghion, Mark Aguiar, Daron Acemoglu, David Autor, Abhijit Banerjee, Esther Duflo, Erica Field, Mikhail Golosov, Bob Gregory, Chang-Tai Hsieh, Oleg Itskhoki, Nobu Kiyotaki, David Lee, Randall Morck, Cece Rhodes, Richard Rogerson, Gerard Roland, Chris Sims, Chris Udry, Shing-Yi Wang, Chris Woodruff and Fabrizio Zilibotti for their insights. We thank seminar and conference participants at Princeton, Chicago, Harvard Business School, MIT, Yale, China Summer Institute, NEUDC, SMERU (Jakarta) and the NBER Summer Institute Meetings for their comments and suggestions. Guofang Huang, Zhichao Wei, Liu Yanliang and Ning Ding provided excellent research assistance. The authors gratefully acknowledge research funding from the Australian Research Council and Harvard Business School.

†Harvard Business School; liyer@hbs.edu

¥Australian National University; xin.meng@anu.rpss.edu.au

§Yale University, NBER, BREAD, CEPR; nancy.qian@yale.edu

IDuke University; xiaoxue.zhao@duke.edu 


\section{Introduction}

One of the key economic and historic events of the late 20th Century is the transition of centrally planned socialist economies to market economies. According to the International Monetary Fund, 36 countries have experienced economic transition, affecting over $40 \%$ of the world's population, only ten of which have completed the process (Barnett et al., 2000). An essential component of economic transition is the movement of labor from state employment to private employment. This has featured prominently in the IMF's policy recommendations to Eastern European transition economies during the early 1990s (Mitra et al., 2002) and in the highly profiled China 2030 report by the World Bank and the Chinese State Council (World Bank, 2012, p. 88).

While improving labor allocation could be beneficial in the long run, policy makers must also consider the costs of such policies in the short-to-medium term. If short-to-medium run labor demand elasticity in the private sector is low, then large and sudden increases in labor supply to the private sector can result in significant wage and income reductions, or even job losses for workers. This can, in turn, lead to political and social instability. Thus, understanding the policies that governments of transitioning economies can employ to gradually reallocate state-sector workers to the private sector and the ability of an infant private sector to absorb labor are first order concerns for policy makers today.

The goal of our paper is to make progress on these questions with novel and rigorous empirical evidence in the context of urban China. First, we provide evidence that reducing employer-provided benefits increased private-sector labor supply. In our case, we study the untying of access to urban housing from state-sector employment. Second, we use the urban housing reforms to instrument for private-sector labor supply and estimate the labor demand elasticity in the urban private sector. 
The Chinese context offers several advantages for understanding the mechanisms underlying economic transition. In contrast to Eastern Europe, the Chinese transition process took place under political and macroeconomic stability, and there was considerable variation in the timing of economic reforms across Chinese provinces and cities, which enables econometric identification. ${ }^{1}$ The limited population migration across cities in China enables us to treat each city's labor market as relatively isolated. Though there was no comprehensive firm-level survey in the early transition years, we are able to use China's Urban Household Income and Expenditure Surveys (UHIES) to measure employment status, housing ownership and wages. These data are of high quality. Private enterprises in this household survey are businesses started by individual entrepreneurs and are distinct from privatized state firms.

Our study proceeds in several steps. First, we construct a unique dataset on citylevel reform dates using information from province-level newspapers in the National Library archives in Beijing. Our main variable of interest is the date of the first reform which untied access to housing from state-sector employment. ${ }^{2}$ About five to ten years later, a second reform allowed residents to trade (sell, buy, lease) this newly acquired housing. We also collected information on the dates of the second reform to ensure that our results are not driven by the possibility of monetizing the housing. We combine the data on reform dates with UHIES household survey data for a panel of 27 cities over 1986-2005.

The reforms were introduced at different times across cities. According to conventional wisdom, the timing of the reforms was mostly determined by the needs of budget-constrained city governments to devolve their responsibility for providing worker housing. Consistent with this, we find that cities with lower government

\footnotetext{
${ }^{1}$ Other studies which exploit such variation across provinces include Lin (1992), who examines the impact of the Household Responsibility System.

${ }^{2}$ These reforms have been enacted in at least 50 Chinese cities, affecting more than 90 million people, making it the largest urban property reform in history.
} 
revenues in the early 1980s are likely to introduce housing reform earlier. Using a difference-in-differences approach, we compare labor market choices of households before and after the introduction of the housing reform, between cities that have already introduced it to those that have not. Our estimates control for city fixed effects, which control for all time-invariant differences across cities, and year fixed effects, which control for all changes over time that affect cities similarly, such as macroeconomic changes or introduction of national policies (including the national law on urban housing reform enacted in 1994). Since the timing of the reform was determined in part by city government revenues, we also control for pre-reform city government revenues interacted with year fixed effects.

Second, we examine the effect of the housing reform on housing and employment status. Between 1986 and 2005, employment in private firms increased from zero to $6.7 \%$ of the total urban labor force. ${ }^{3}$ We find that the housing reform accounts for 30 percent of the total increase in labor supply to private enterprises. This is driven by an increase in the number of workers employed by private businesses rather than the number of business owners (i.e. entrepreneurs). The distinction is important since self-employment in small private businesses may also reflect disguised unemployment. A possible concern is that the effects of housing reform may be confounded with the effects of other concurrent changes, such as overall provincial growth or the restructuring of the state sector, that can also affect private-sector employment. We conduct a large number of robustness exercises to show that our estimates are unlikely to be biased by such factors.

Third, we use the reform-driven increase in the private-sector labor supply to

\footnotetext{
${ }^{3}$ Note that our definition of the private sector is more stringent than most other studies about the Chinese economy in that we examine owners or workers of small businesses owned by individual proprietors. We do not include large enterprises that were formerly state-owned or grew from stateowned enterprises because such firms typically behaved like state firms with respect to the housing reform. We discuss this in more detail in Section 4.
} 
estimate the wage elasticity of labor demand in the private sector. We find that increasing the labor force by $1 \%$ reduces wages by approximately $0.18 \%$ to $0.32 \%$ in the private sector, which implies a labor demand elasticity of approximately 3.1 to 5.5. Note that since we observe the cities in our sample for up to at least eight years after the introduction of the housing reform, our labor demand estimates are the average of the short and medium-run effects.

In addition to the main analysis, we provide suggestive evidence on the dynamics of private- and state-sector wages and find that prior to the reform, the residualized wages (controlling for individual characteristics and city fixed effects) are higher in the private sector. When the reform is introduced, wages immediately converge between the two sectors, suggesting that the increase in labor mobility eliminated the rents earned by private-sector workers.

Our findings contribute to a large literature on economic transition and structural change. Existing empirical studies in this literature have mostly been descriptive or have focused on cross-country comparisons. ${ }^{4}$ We add to these by using micro data and a policy experiment to provide detailed and well-identified evidence that untying benefits from state-sector employment can be an effective policy for gradually releasing labor into the private sector, and that private-sector labor demand can be elastic even when the sector is young and very small. ${ }^{5}$ Finding that labor demand is highly elastic is consistent with past studies which find that private enterprises

\footnotetext{
${ }^{4}$ The literature on transition is large and space constraints prevent us from citing all of the papers. Please see Guriev and Megginson (1997), Megginson and Netter (2001) and Roland (2002) for overviews of this literature. Also, see Aghion et al. (1994) for details of the transition experience in Eastern Europe, Shleifer (2005) for a review of the evidence on Russia, and Rutkowski (1996) and Svejnar (1999) for empirical overviews of the labor market during transition in Eastern Europe.

${ }^{5}$ There is a large literature in labor economics on labor demand estimation. Our empirical strategy is conceptually similar to Acemoglu et al. (2004), who use a policy shock to female labor supply during World War II to study the U.S. wage structure. Also, see Card (1990) and Angrist (1996) for seminal studies that use policy-driven labor movements to identify the impact of supply shocks on wages. The effect of employment-provided benefits on labor mobility has been discussed in the labor and public economics literature on "job-lock". For example, see Gruber and Madrian (2002) for a discussion of employer-provided health benefits in the United States.
} 
are important for job creation (e.g. Berkowitz and DeJong, 2001; McMillan and Woodruff, 2002), and can absorb labor from the state sector (Bilsen and Konings, 1998; Faggio and Konings, 1999) in other transitioning economies. The evidence that the increase in labor mobility reduced private-sector rents adds to studies that investigate why privatization policies are unpopular despite their obvious benefits to the economy at large (e.g., Denisova et al., 2009; Fernandez and Rodrik, 1991; Zhuravskaya, 2007). Since the increased movement to the private sector caused by the housing reform was gradual and voluntary, our results provide some support for gradual transition (e.g., Aghion, 1993; Roland, 1994). The empirical findings are also consistent with the theoretical study by Aghion and Blanchard (1994), which argues that to avoid unemployment and wage reductions, private-sector job creation should take priority over state-sector restructuring even if shedding labor from the state sector will increase productivity. ${ }^{6}$

Our general finding that the housing reform had a large effect on urban labor market choices is consistent with the work of Wang (2012), which finds that housing reforms increased entrepreneurship and attributes this finding to relaxed credit constraints. We differ from her study in focusing more on general equilibrium effects and estimating the private-sector labor demand elasticity, which she does not examine. Wang (2012) compares individuals that were previously employed in the state sector to those that were not, before and after 1994, the date of the national housing reform law. However, we find that most of the cities in our data had already enacted the housing reform prior to the national law. Our empirical strategy therefore compares the effects of reforms across cities before and after implementation, using city-specific reform dates that began in 1988 and ended in 1997. The different strategies may explain why we find no effects on entrepreneurship.

\footnotetext{
${ }^{6}$ Kikeri (1998) provides a review of what happens to labor when governments divest from firms.
} 
This study is organized as follows. Section 2 discusses the background on privatization and housing reforms. Section 3 presents a simple theoretical framework and discusses our identification strategy and Section 4 describes the data. In Section 5, we estimate the effect of the housing reform on employment decisions and in Section 6 , we estimate labor demand elasticity for the private sector. Section 7 offers concluding remarks.

\section{Private Enterprise and Housing Reform in Urban China}

\subsection{Urban Economic Transition}

As with many other transitioning economies, the Chinese government's official position during the early period of transition was to tolerate and not interfere with the emerging market economy, rather than to proactively assist it. Private enterprises therefore faced several barriers to growth during the period of our study, 1986-2005, including limited access to formal credit and legal contract enforcement. For example, in 2003, even with the most expansive definition of what constitutes a private enterprise, the private sector accounted for only $1.75 \%$ of loans from all formal financial institutions in China. ${ }^{7}$ With the encouragement of the China Development Bank, banks began to make loans to small and medium enterprises starting in $2004 .^{8}$ The stock market was also of little use to new enterprises since a firm needs to reach a certain size before it can become public. Of the 976 companies listed on the Shanghai and Shenzhen stock exchanges in 1999, only eleven were non-state firms (Huang, 2003). It is widely believed that new enterprises mostly raised capital with own savings and informal credit (McMillan and Woodruff, 2001). Private enterprises

\footnotetext{
${ }^{7}$ Data from China Industrial Statistical Year Book 2004 and the Almanac of China's Finance and Banking 2005.

${ }^{8}$ Interviews by authors with officials in the China Development Bank, who described government policies about bank loans to private enterprises.
} 
also lacked access to legal contract enforcement. ${ }^{9}$ The presence of credit constraints and limited contract enforcement is important to keep in mind for interpreting the results since they can limit firm growth. Despite the lack of contract enforcement, it is widely believed that Chinese business owners faced little government predation and a low risk of expropriation, which may have encouraged private-sector growth relative to other low- and middle-income countries. ${ }^{10}$

Large-scale restructuring of the state sector mostly occurred during 1993-1998. These reforms divided state-owned enterprises (SOEs) into three groups: firms that continued to be directly owned and financially supported by the state, firms that were allowed to sell equity to non-government entities to raise capital (e.g., other SOEs and private entities) and firms that were shut down. The second group of "mixed-ownership" firms are among those classified as "other ownership" in our data, though the state continued to have a leading role in the control of such firms. For example, data from the 1998 Census for Manufacturing Firms show that the state is the majority equity holder in the average manufacturing firm of mixed ownership; less than $10 \%$ of equity is held by individuals. With political stability as the ultimate objective, the government was cautious in ensuring that enterprise reform did not alter urban public goods and social security, which were mostly provided by SOEs (e.g., Bai et al., 2001; Bai et al., 2006). Thus, when ownership changed from being state to mixed, the new mixed ownership enterprise continued to provide similar benefits as the state enterprise did previously.

It is important to consider the effect of the enterprise restructuring on unem-

\footnotetext{
${ }^{9}$ The details of the legal reforms are described on the Chinese government website http://www.law110.com/law/guowuyuan.htm (in Chinese). See Meng (2000) for a detailed description of Chinese labor market reforms.

${ }^{10}$ For example, Bai et al. (1999) provide evidence that one mechanism for avoiding predation was to provide urban residents with anonymous bank accounts. See McMillan and Woodruff (2002) for a comparison of the environment faced by Chinese entrepreneurs relative to those in Vietnam and Eastern European countries. Note that their discussion mostly focuses on the early parts of the Chinese transition, which was mostly driven by rural TVEs.
} 
ployment. The Chinese government was committed to keeping urban unemployment rates low during transition and past studies have found that enterprise reforms did not reduce total employment (Bai et al., 2009). However, workers of both state and mixed ownership firms were often forced to take early retirement, before the official retirement age of 55 for women and 60 for men) (Giles et al., 2006). These workers are not counted as being in the labor force and thus do not contribute to unemployment statistics. Some of these workers, who might find alternative employment after official retirement, are listed as "retired and re-employed" in the UHIES data (also known as xiagang workers). We therefore create a broad measure of unemployment to include people no longer in the labor force. In our empirical analysis, we examine both "unemployment" and "retired and re-employed" as separate labor market indicators, and verify that neither of these is correlated with the timing of urban housing reforms.

\subsection{Urban Housing Reforms}

Until the post-Mao reforms, almost all urban workers worked for SOEs. Leaving state employment was extremely costly as it was tied to a range of benefits, the most important of which was employer-provided housing. Historically, urban housing was allocated by SOEs to workers at a highly subsidized rent. The subsidies were financed by the city government.

Housing reforms began in the mid-1980s, as part of the general movement towards a market economy and also because city governments wanted to be relieved of the responsibilities of providing housing. It was administratively cumbersome to allocate housing and the gap between the maintenance cost of the state-owned apartments and the nominal rents paid by the residents grew over time (Duda et al., 2005). The rising costs of urban housing provision for city budgets became increasingly 
problematic as city government revenues from SOEs declined during the early part of the reform era. In the late 1980s, cities with the most pressing budgetary problems began to push for reforms that would include selling off part of the old state owned housing (Yuan, 2000; Pan, 2000). These reforms allowed part of the state-owned housing to be sold to employees at a subsidized price. New workers in the state sector would no longer be eligible for state housing but workers who left their state jobs could remain in the same housing if they had purchased it. This effectively untied access to housing from state-sector employment.

The pricing of housing purchases was decided by city governments with inputs from SOEs. Prices took into account the age, size, location and quality of the housing. ${ }^{11}$ In addition, workers were offered "concessions" (price reductions) based on their characteristics. The most important was based on job tenure: the longer the tenure at the work unit, the higher the concession (Wang and Murie, 1999). In 1994, the central government codified the housing reform as a national law called the Urban Real Estate Administration Act to be officially "enacted" in 1995. Since most cities in our sample had already implemented the reform by then, we do not use 1994 as a reform date. Instead, our empirical strategy will use the city-specific introduction dates.

The wealth gains from the reform are unclear ex ante. We should note that households enjoyed considerable rental subsidies when living in state-owned housing. According to our data, during 2001-2005, a person who rented from the state paid on average $271 \mathrm{RMB}(26 \mathrm{RMB} / \mathrm{sq} \mathrm{m})$ per month, while a person who rented from a private owner pays on average 1,362 RMB (71 RMB/sq m). Wang (2012) uses price and rent subsidy data from the China Household Income Project and calculates that

\footnotetext{
${ }^{11}$ The basic guideline was that the price of a new apartment should not be higher than three times the average household annual income in a city. If buying an older house, the price should be adjusted according to a depreciation formula that fully depreciated the house over 75 years.
} 
the average price subsidy for purchase was approximately 24,462 RMB while the present discounted value of rental subsidies was approximately 20,223 RMB. She concludes from this that the subsidized purchase price offered in the housing reforms did little to increase overall household wealth.

The gains in wealth, moreover, were difficult to realize in practice. Privately owned housing could not be sold until the implementation of a second reform which allowed the trading of housing on the market. We collect data on the date of this second policy and include it as an additional control in our robustness checks, to verify that our results are not arising due to wealth gains for households. Furthermore, we should note that state-owned banks did not make loans to households until very recently. Therefore, new property owners did not have the ability to use their newly acquired housing as collateral for business or other types of loans.

\section{Conceptual Framework}

\subsection{Private Sector Labor Supply and Wages}

To frame the key questions of this investigation, it is useful to briefly discuss the theoretical implications of an increase in labor supply to the private sector. For simplicity, let us assume that the labor market is competitive, and that the private sector uses two factors: labor $(L)$, and capital $(K)$ which represents all non-labor inputs. In particular, consider the simple Cobb-Douglas aggregate production function:

$$
Y=A K^{\alpha}(L)^{1-\alpha},
$$

where $A$ is the total factor productivity for the private sector, and, $0 \leq \alpha \leq 1$ and

$0 \leq 1-\alpha \leq 1$ are the output elasticities of capital and labor.

Because the labor market is competitive, the wage is determined by the marginal 
product of labor. The private-sector wage is thus

$$
w=(1-\alpha) A K^{\alpha} L^{-\alpha}
$$

The effects of an increase in labor supply will, in general, depend on how capital and technology adjust in response to the labor shift:

$$
\frac{\partial \ln (w)}{\partial \ln (L)}=-\alpha+\alpha \frac{\partial \ln (K)}{\partial \ln (L)}+\frac{\partial \ln (A)}{\partial \ln (L)} .
$$

In this expression, $-\alpha$ reflects the direct effect of labor change on wages, while $\alpha \frac{\partial \ln (K)}{\partial \ln (L)}+\frac{\partial \ln (A)}{\partial \ln (L)}$ represents the indirect effect due to the response of the stock of capital and technology to the change in labor. Since capital and technology are likely to adjust more slowly than labor, we assume that the level of capital stock and technology are held constant in the short run and therefore, the indirect effect of labor movement caused by capital and technology response will be zero. Thus, $\frac{\partial \ln (w)}{\partial \ln (L)}=-\alpha$, and we obtain a short-run wage elasticity with respect to labor of $-1 / \alpha$.

Our main goal is to estimate $\alpha$ for the private sector. There are two important points to keep in mind for the interpretation. First, our data observe cities for at least eight years after the housing reform. Given the rapid economic growth in urban China during this period, it is unlikely that physical capital and technology are not increasing in the private sector over this period of time. Since improvements in capital and technology mitigates the negative effect of labor supply on wages, the elasticity estimates we obtain will be larger in magnitude than the actual short-run elasticity . Second, while we believe that the private sector pays competitive wages that equal the marginal product of labor, the state sector most likely does not. Therefore, our empirical analysis will focus on interpreting the private-sector wage elasticity and will not attempt to estimate the wage elasticity for the state sector. 


\subsection{Identifying the Effects of Housing Reform on Labor Realloca- tion}

We examine the effect of the housing reforms on household level outcomes using

a difference-in-differences specification, which compares household outcomes before and after the housing reform is implemented in a city:

$$
y_{h j t}=\theta H_{j t}+\psi X_{h j t}+\gamma_{j}+\delta_{t}+\varepsilon_{h i t},
$$

where outcome $y_{h j t}$ is the outcome (housing status, labor market choice) for household $h$ in city $j$ during year $t$. This is modeled as a function of a dummy variable that equals one if the urban housing reform had taken place in that city, $H_{j t}$; a vector of individual controls that includes sex, age and the years of education of the household head, $X_{h i t}$; a city dummy variable, $\gamma_{j}$; and a year dummy variable, $\delta_{t}$. Our coefficient of interest is $\theta$, which captures the effect of urban housing reform. To adjust for the fact that households in the same city might face correlated shocks in the same year, we cluster all our standard errors at the city level. Since such clustering may produce downward biased standard errors when the number of clusters is not large (we have 27 clusters), we also implement a clustered wild bootstrap estimation to test the significance of our coefficients (Cameron et al., 2008). Both sets of p-values are reported in the tables. Almost all of our results survive the stringent bootstrapping. Thus, for brevity, we do not discuss them after this point.

Causal identification assumes that the outcome of interest and the introduction of the reform are not joint outcomes of an omitted variable. For example, one obvious concern is that private-sector employment and the housing reform might both be driven by a poorly performing state sector. This could push workers from the state sector into the private sector and cause budget-constrained city governments, which 
rely partially on state owned enterprises for revenues, to privatize housing. However, the main determinant of the timing of the reforms, city government income prior to the reform, is already controlled for by the city fixed effects, along with all other time-invariant differences across cities. Nevertheless, to account for the possibility that cities with lower pre-reform revenues were on a different trajectory, we estimate specifications controlling for pre-reform city revenues interacted with year dummies. Similarly, any changes over time that affect all cities similarly over time are controlled for by the year fixed effects. This includes nationwide macroeconomic changes as well as other policy changes such as the introduction of a central government urban housing reforms in 1994. We also run robustness checks controlling for other concurrent regional changes such as provincial GDP growth rates, provincial growth rates of state-sector employment and the date of the subsequent trading reforms. Finally, we also control for pre-reform trends in our key variables of interest, to verify that what we observe is not a simple continuation of such trends.

In terms of mechanisms which might drive the relationship between housing reforms and movement towards the private sector, our preferred explanation is the removal of "job-lock" caused by the state's provision of housing. A different potential mechanism could be wealth effects which might lead people to invest in new private businesses, and thereby generate greater demand for private sector labor. As discussed in Section 2.2, existing estimates suggest a very small net wealth effect of the housing reform, which moreover could not be monetized due to the constraints in the Chinese financial sector. We also directly verify that housing reforms did not lead to a significant increase in new private sector businesses or self-employment. 


\subsection{Estimating the Elasticity of Private-Sector Labor Demand}

We use the urban housing reform as an instrument for labor supply to the private sector to estimate the labor demand elasticity. This can be done by using only the private sector sample. However, since the choice of an individual to work in the private sector is partly determined by the reform, this would effectively be conditioning on an endogenous variable. Instead, we use the full sample and estimate the following equation by two stage least squares (2SLS):

$$
\ln w_{i j t}^{k}=\pi_{1} \ln L^{p}{ }_{j t}+\pi_{2}\left[\ln L^{p}{ }_{j t} \times P_{i j t}\right]+X_{j t}^{\prime} \gamma_{k}+Z_{i j t}^{\prime} \zeta_{l}+\gamma_{j}+\delta_{t}+\varepsilon_{i j t}
$$

where $\ln w_{i j t}^{k}$, the $\log$ wage of individual $i$ living in city $j$ during year $t$ and who works in sector $k$ (private, state) is a function of the log of the total number of workers in the private sector, $\ln L^{p}{ }_{j t}$; the interaction between the $\log$ number workers in the private sector and a dummy variable for whether individual $i$ works in the private sector, $P_{i j t}$. We control for a vector of individual controls such as the sex, age and years of education, $Z_{i j t}$; a vector of time-varying city characteristics that we introduce later in the robustness checks, $X_{j t}$; city and year fixed effects. As before, our standard errors are clustered at the city level. ${ }^{12}$ The main effect of whether an individual works in the private sector is also included in the vector of individual controls.

Our estimation strategy closely resembles that of Acemoglu et al. (2004), which used variations in female labor supply across U.S. states to estimate the elasticity of demand for female workers. ${ }^{13}$ This strategy requires several assumptions. First,

\footnotetext{
${ }^{12}$ Note that we are unable to implement Wild bootstrap for the 2SLS standard errors. However, since most of the results on housing and employment status show that p-values are similar between the bootstrapped and non-bootstrapped methods. Thus, we believe that the standard errors are unlikely to be attenuated by the small number of clusters.

${ }^{13}$ While Acemoglu et al. (2004) use the ratio of weeks worked by women and men as the measure of relative female labor supply, we use the number of private-sector workers in each city. There are two reasons for this. First, we do not have data on hours or weeks worked in our survey. Second, as we will demonstrate, overall labor force participation rates did not change after housing reform, so that using the number of private-sector workers is equivalent to using the relative number of 
since we are using cross-city variation in labor supply, the implicit assumption is that these cities are independent labor markets. For the context of our study, where the reforms are mostly being introduced in the late 1980s and early 1990s, this assumption is plausible since migration between cities was tightly restricted by policy. Based on statistics from the census, cross-city migrants were only 1.37 percent of the population in 1990 and 6.3 percent in 2000. Second, inter-city trade can be a source of factor price equalization across cities even in the absence of worker migration. However, cross-province trade in China was inhibited by the presence of inter-province tariff and non-tariff barriers throughout the 1990s (Poncet, 2005). Third, as mentioned in Section 3.2, long-run elasticities can be very different as capital or technology adjusts to these changes in labor supply.

Finally, to avoid the simultaneity bias, we need an exogenous determinant of labor supply. For this, we use the introduction of the housing reform. The private-sector labor supply, $\ln L^{p}{ }_{j t}$, is instrumented by the introduction of the housing reform; and the interaction variable, $\ln L^{p}{ }_{j t} \times P_{i j t}$, is instrumented by the interaction of the introduction of the housing reform and a dummy for whether an individual works in the private sector. These two instrumented terms can be interpreted as exogenous (whereas the main effect of whether an individual works in the private sector is an endogenous choice variable). $\hat{\pi}_{1}$ is the estimated average effect of a change on private-sector labor supply on the wages of non-private-sector workers. $\hat{\pi}_{1}+\hat{\pi}_{2}$ is the estimated effect of a change in private-sector wages due to a change in privatesector labor supply (the inverse of the labor demand elasticity). As such, we expect $\hat{\pi}_{1}+\hat{\pi}_{2}$ to be negative. Since state-sector wages may not equal the marginal product of labor, we do not have any a priori expectation on the sign of the coefficient $\pi_{1}$, which represents the impact of private-sector labor supply on state-sector wages.

workers in the private sector (in the log-log specification). 
Our regressions in Section 3.2 will show that individuals' labor supply choices are responsive to the implementation of housing reform. For the labor demand elasticity estimation, we will first verify that the aggregate private-sector labor supply (obtained by summing the total number of household heads and spouses) also responds to the housing reform by running the following "first stage" equation:

$$
\ln L^{k}{ }_{j t}=\varphi_{0} H_{j t} \text { postreform }_{j t}+X_{j t}^{\prime} \gamma_{k}+Z_{i j t}^{\prime} \zeta_{l}+\gamma_{j}+\delta_{t}+\varepsilon_{i j t}^{k}
$$

where the log number of workers in city $j$ during year $t$ and sector $k$ is a function of: a dummy variable indicating that the housing reform has taken place $H_{j t}$, and the same controls as in the second stage equation (5).

Our identification strategy might yield biased estimates if urban housing reforms also have an effect on other dimensions of labor supply and labor demand. An important consideration, especially for the later years in our sample, is the large numbers of rural-to-urban migrants who are predominantly employed in the private sector. This will cause the private-sector labor supply to be larger than what is reported in the household survey since the survey will miss many migrant workers. We will therefore present robustness checks which adjust for the fraction of migrants in the city's labor force. Another concern is that housing reforms could also increase the demand for labor and average wages in the private sector, if it gives rise to large scale private development of residential housing. The presence of such a construction boom will cause our instrumented estimates to under-state the wage reduction caused by increases in private-sector labor supply, and thereby overestimate the demand elasticity. 


\section{Data}

\subsection{The Urban Household Income and Expenditure Surveys}

We obtained household survey data from the Urban Household Income and Expenditure Surveys (UHIES) conducted by China's National Bureau of Statistics. The UHIES is a $0.01 \%$ stratified random sample of the urban population. We have access to the UHIES data for 27 cities in fifteen provinces for the years 1986-2005. The data is a repeated cross-section of households. Only $11 \%$ of households owned their own housing before the introduction of the housing reforms, whereas $73 \%$ owned their housing afterward. This increase is paralleled by a decline in the percentage of households that rent from the state from $86 \%$ to $23 \%$ (Table 1, Panel A). ${ }^{14}$

Our employment and wage analysis will focus on household heads. For our data, the definition of household head is arbitrary as it depends on who happens to be at home to respond to the survey when the surveyor arrives. Since the average household size in our sample is three, this means that the omitted members are typically the spouse and a dependent child. ${ }^{15}$ In our sample, the average household head is more likely to be male, approximately fifty years of age and has twelve years of education (Table 1, Panel B).

The UHIES categorizes employment into the following categories: i) employed by a state-owned enterprise; ii) employed by a collective-owned enterprise; iii) employed by "other" enterprise; iv) employed by a private enterprise; v) self-employed or small enterprise owner (hereafter referred to as "self-employed"); vi) retired and re-employed; and vii) other. We classify individuals in categories (i) and (ii) as statesector workers. The category "other enterprises" presents a difficulty in classification:

\footnotetext{
${ }^{14}$ The share of households owning housing and renting from the state does not add up to $100 \%$; the remainder comprise those who rent from the private sector and those who live in "other" types of housing.

${ }^{15}$ We show in the appendix that our estimates are similar for the spouse as well as when we examine all adult household members. For brevity, we will not discuss these results.
} 
this includes partially privatized state-owned firms (in many cases, the state retains a controlling share), as well as joint ventures, foreign owned firms and township and village enterprises (TVEs). ${ }^{16}$ Since we are unable to assign this category to either state or private sector in any meaningful way, we exclude this category from our main regressions for sector of employment and wages. ${ }^{17}$

The UHIES does not report unemployment. To examine this outcome, we construct a broad measure of unemployment based on the number of workers who report no sector of employment. ${ }^{18}$ Since this measure includes those who are still in school, those who are unable to work because of disability, and those who voluntarily choose to exit the labor force, it should be interpreted as an upper-bound of unemployment rates. Consistent with increasing state-sector restructuring over time, we see that it grows from seven to seventeen percentage-points from before to after the reform. ${ }^{19}$

To examine the sector of employment, we restrict the sample to households where the head reports a non-missing value for this variable. The descriptive statistics are very stark. Prior to the reform, there was virtually no one in the private sector. After the reform, $5 \%$ of the sample report as being employed by a private enterprise, while $4 \%$ report being self-employed or owning a small enterprise. Analogously, we see a decline of state-sector employment from $97 \%$ to $80 \%$. Consistent with economic restructuring, we find that the number of "retired and re-employed" workers increase

\footnotetext{
${ }^{16}$ We examined the composition of this category in some detail using the China Household Income Project (CHIP) dataset. Less than one-fourth of these "other enterprises" were joint ventures or foreign owned in 2005, about half were state-controlled and the rest were of unknown ("other") ownership.

${ }^{17}$ Since such "mixed" enterprises often had housing policies similar to state-owned firms, we also conduct robustness checks where we classify these as part of the state sector. Our results change very little with this addition. The results are available upon request.

${ }^{18}$ We restrict our sample to those between 20 and 80 years of age.

${ }^{19}$ We also computed unemployment rates after excluding those who are no longer in the labor force, along the same lines as Feng et al. (2015). We have verified that housing reforms do not have an impact on this more traditional measure of unemployment (results available upon request). We prefer our broader measure since that accounts for any potential misclassification of whether someone is in the labor force, and because exiting the labor force might also be a response to other policy changes such as SOE restructuring.
} 
from 1 to $8 \%$.

The UHIES reports total labor earnings for each individual, which we use a proxy for wages in the absence of data on the amount of time worked. Therefore, our results should be cautiously interpreted bearing in mind that we assume that the number of hours worked does not change systematically with the introduction of the housing reform. Also, the survey questions regarding household income were changed after 1988. For consistency, we do not examine wages prior to 1989 , which reduces the sample size available for estimation of labor demand elasticity. Consistent with the strong growth of the Chinese economy in the 1990s, average real wages more than doubled in the post-reform period compared to the pre-reform period. ${ }^{20}$

One of the drawbacks of our data is that it under-counts migrant laborers. Before 2002, the survey only sampled households with urban household registrations. Even after 2002, only a very limited number of households with rural household registration are included in the survey (e.g. only $2 \%$ of the sample in 2003 have rural registration). ${ }^{21}$ For consistency, individuals with rural household registration in the 2002-2005 surveys are excluded from sample for the main analysis. However, the undercounting of migrants means that we underestimate the increase in private-sector labor supply, potentially leading to underestimation of labor demand elasticity. To address this problem, we obtained independent city-level estimates of the fraction of migrants in the labor force in 1990, 2000 and 2005, and use these to construct alternative estimates of the private-sector labor supply in each city. We also collected data on city-level GDP and government revenue, and province-level GDP growth and state-sector employment growth rates. These data were obtained from province and city-level statistical yearbooks, and will be used as robustness controls for our

\footnotetext{
${ }^{20}$ Note that these data are not adjusted for inflation, which was low during this period. In the regressions, price changes are controlled for by the year fixed effects.

${ }^{21}$ This is probably because the majority of rural-urban migrants either live on the periphery of cities where rents are cheaper or in dormitories or workplaces such as construction sites.
} 
regression analysis.

\subsection{Housing Reforms}

We construct a unique data set of housing reform dates by collecting information on the date when workers were first allowed to buy their houses from their work units. We will refer to this reform as the "housing reform" hereafter. We also collected data on the dates of the introduction of subsequent housing reforms that allowed owners of private housing to rent or sell on the market (referred to as the "second reform"). Information on both reforms was obtained by a search of the city-level newspapers. Our final data set contains 27 prefecture or higher level cities for which we have both the reform date and household data over the entire 1986-2005 period. ${ }^{22}$

The cities in our sample began to implement the reform in 1988. By the time that the national law was proclaimed in 1994, $93 \%$ of the cities had already introduced the housing reform. The last city to introduce the housing reform did so in 1997 (see Appendix Table A.1). These statistics reveal several important facts. First, they show that there is substantial variation in the timing of the introduction of the housing reform for our empirical strategy to exploit. Second, the fact that the earliest reforms occurred at the beginning of the period of our study means that we will not be able to examine pre-trends for each year before the reform without losing a substantial number of observations. Third, since $93 \%$ of cities had already introduced the housing reform by 1994, it would be inappropriate to use the national

\footnotetext{
${ }^{22}$ The household survey covers 16 provinces or municipalities over 1986-2005, comprising 100 cities before 2002 and 238 city codes from 2002. We have housing reform dates for 42 of these cities. However, only 28 of the 42 cities were included in the pre-2002 surveys. Of these, one was a county-level city which was excluded to preserve comparability within the sample. The remaining 27 cities are all prefecture or higher level cities, and include all the provincial capitals or municipalities. Our data comprises around $40 \%$ of the households for the pre-2002 surveys and one-third of households for the surveys since 2002. The cities excluded from our final data set are largely smaller or newly established cities. Because of this dominance of large cities, households in our final data set have higher income, more educated household heads, and smaller household sizes relative to the households which are not included.
} 
law in 1994 as a uniform reform date for all of China. Finally, the fact that the last city to implement the housing reform did so in 1997 means that our analysis, which uses data up to 2005, should be interpreted as the effect of labor supply shifts on wages for an eight-year period (i.e. the average of the short- and medium-run effects).

According to the qualitative evidence, low government revenues was the main determinant of early introduction. We check whether this was true on average by examining the correlation between housing reform timing and city government revenues, which are reported by city-level statistical yearbooks. We aggregate our data to the city level and estimate the correlation between the year of introduction and the pre-reform average log government revenue measured in 1980-1986. When we regress the year of the housing reform on log city government revenues, we find that the $\mathrm{R}$-square is 0.82 , which means that pre-reform city government revenues explains $82 \%$ of the variation in the timing of the reforms across cities (results not shown in tables). This provides strong support for the belief that the main determinant of timing of the housing reform was pre-reform city government revenues.

Before presenting the regression results, we examine the evolution of the outcomes of interest before and after the introduction of the housing reform to see whether there is a pre-trend. This also allows us to investigate whether the outcomes begin to change when the reform is introduced. Otherwise, we would be concerned that our post-reform estimates capture spurious trends. Figure 1 plots private housing ownership against the number of years since the housing reform. Year "0" indicates the first year of the reform. It shows little change over time prior to the housing reform and then a gradual but continuous rise afterwards. Figure 2 plots the analogous figure for the fraction of workers employed by a private enterprise. It shows that there are almost no workers in the private sector prior to the housing reform, but afterwards, there is a gradual and continuous increase. Both figures indicate that 
there is no pre-trend prior to the introduction of the housing reform and the trend break in the outcomes occurs at the time of the reform. Figure 3 plots private-sector entrepreneurship against the number of years since the housing reform. Although there is an increase over time, we see that the gradual increase begins three years prior to the reform.

\section{The Effect of the Housing Reform on Housing Status and Labor Supply}

\section{$5.1 \quad$ Housing Status}

Using the difference-in-difference specification shown in equation (4), we find that the housing reform increased the probability of a household owning their home by 6.8 percentage-points (table 2 , column 1 ). The coefficient is statistically significant at the $10 \%$ level. The baseline estimates control for the age, sex and years of educational attainment of the household head. In column (2), we additionally control for the quadratic terms of the age and schooling of the household head to allow their influences to be non-linear. The estimates are unchanged. In column (3), we include controls for the interaction of year fixed effects with the household head's age and with her education. This is to address the fact that the returns to age and education may change as the economy liberalizes. Our estimates are larger in magnitude and statistical significance with this specification.

\subsection{Private-Sector Employment}

We find that individuals are significantly more likely to be involved in private-sector work after cities implement urban housing reforms (Table 3, column 1). The reform increased the probability of a household head working for a private business by two 
percentage-points, which is statistically significant at the $5 \%$ level. The estimates are very robust to different ways of controlling for individual characteristics in columns (2) and (3). In contrast, we find no effect of housing reform on the probability of the household head being self-employed or owning a small enterprise (columns 4-6). The coefficient is small in magnitude and statistically insignificant.

Given that the overall probability of employment in the private sector increased from zero to 6.7 percent over the period 1986-2005, our estimates imply that housing reforms account for 30 percent of the overall increase in private-sector employment over this period. Similarly, since total private-sector employment - i.e., including employees and self-employed/small enterprise owners - increased from zero to 12.1 percent, our estimates imply that the reform explains approximately $16.5 \%$ of the overall increase in private-sector labor supply.

The probability of renting housing from the state or state-sector employment are both decreasing almost one-for-one with the increase in private housing and privatesector employment respectively, though the estimated coefficients are statistically insignificant (results available upon request). ${ }^{23}$

\subsection{Layoffs and Unemployment}

The main concern for interpreting the effects of the housing reform on private-sector employment as causal arises from the possibility that the timing of the housing reform and private-sector employment are both outcomes of omitted factors such as a decline in state-sector productivity, or a boom in the private-sector for unrelated reasons (e.g., state enterprise restructuring). In that case, the estimates will confound the impact of the housing reform with the influences of these other factors.

\footnotetext{
${ }^{23}$ That these estimates are imprecise is probably due to the fact that the changes caused by the housing reform are small compared to the total number of state-sector workers and the total number of those that rent from the state.
} 
We investigate this possibility with two placebo exercises.

The most obvious way of investigating whether the housing reforms coincided with the decline of the state sector is to examine the effect of these reforms on unemployment and worker layoffs from SOEs, which were a prominent feature of the enterprise restructuring that took place in the mid and late 1990s. Our first indicator for the health of the state sector is the proportion of "retired and re-employed" workers, which refers to state-sector workers that have gained employment after retiring from the state sector. During the transition process, to increase the profitability of SOEs (and newly privatized firms), workers were often offered early retirement packages. A special category for such workers was created in the UHIES. Therefore, we can investigate the extent to which the housing reform coincided with such voluntary layoffs by examining the effect of the housing reform on the probability that a workers is retired and reemployed. Under our preferred interpretation, the housing reform should have no effect on this placebo outcome. We find that this is indeed the case: housing reforms have no effect on the probability of being retired and re-employed (Table 4, columns 1-3 ).

An obvious drawback of this measure is that it only measures retired or laid-off workers that have successfully regained employment. Some of the workers laid off during SOE restructuring might instead choose to exit the labor force or go back to school for further training. To address this, we construct a second indicator to measure the upper-bound of total unemployment (see Section 4). The sample used for this exercise is larger than the main sample used earlier because the main sample includes only the working age individuals that report some employment. Table 4, columns 4-6 show that the reform had no effect on this broad measure of unemployment. This is consistent with our preferred interpretation that the main effect of housing reforms was to induce workers to enter the private sector. 
The results presented thus far reflect the employment status of the household head. We find similar effects for spouses and for all adult members of the household. For the latter, we use the number of household members working in a given sector as our dependent variable (see Appendix Table A.2).

\subsection{Robustness}

In this section, we show that our results on the increased probability of privatesector employment are not driven by potential confounding variables such as other macroeconomic trends. We focus on employment by a private enterprise since the baseline estimates for self-employment were insignificant.

Further Housing Reforms We begin by controlling for the introduction of the second housing reform that legalized the sale of private housing. Table 5 shows that our main result is robust and the initial housing reform is not confounded by later reforms (column 1). Since the second reform is the one that allowed households to sell or rent (i.e., monetize) their privately owned housing, the robustness of our main estimate means that our main result is present regardless of whether households were allowed to monetize their housing. Since households could also not easily borrow against the expectation of future wealth, this means that our results are unlikely to be driven by wealth effects. Thus, the results are consistent with our preferred interpretation that our estimate of the housing reform effect reflects the reduction in mobility cost caused by untying housing access from state-sector employment.

Macroeconomic Trends Next, we individually control for variables that are correlated with regional economic performance, and in particular, the performance of the state and private sectors in each region, by including province-level GDP growth rates and province-level state-sector employment growth rates as additional regres- 
sors. Neither of these changes the main coefficient on the impact of urban housing reform (Table 5, columns 2-3).

City Characteristics Since the timing of housing reform was in part determined by the city's fiscal needs, we would like to control for city government revenues. However, the implementation of housing reforms could in turn have a direct effect on city government income (e.g. city governments are responsible for funding housing subsidies and are the recipients of the money paid for housing purchases). We instead control for pre-reform city government revenues (averaged over 1986-88), interacted with the full set of year dummy variables. Similarly, coastal regions grew significantly faster than interior regions during the period of our study. We control for this differential growth pattern by including controls for a coastal province dummy interacted with a full set of year dummies (note that the time-invariant effects of being coastal are already captured by the city fixed effects). We find that the effects of housing reform on private sector employment are not confounded by any of these other characteristics; our coefficient increases in magnitude with the inclusion of these controls and retains its statistical significance (Table 5, columns 4-5).

Pre-existing Trends Figure 2 already indicates that our estimates on private sector employment are unlikely to be driven by pre-existing trends. Nevertheless, we control for pre-reform sector-specific employment growth rates interacted with a full set of year dummies. Our estimates are not affected by this specification (Table 5, columns 6-7). We conclude that our main results are unlikely to be driven by omitted variables. 


\section{Private-Sector Labor Demand Elasticity}

\subsection{Main Results}

In this section, we use the housing reform as an instrument for labor supply to estimate the effect of a change in labor supply on wages, using equation (5), where we define the private sector to include both self-employment and working for a private enterprise. The first stage regressions for this two-stage procedure, based on equation (6) are shown in Appendix Table A.3. As we might expect, the housing reform strongly predicts total private-sector labor supply. ${ }^{24}$

The instrumented second stage is presented in Table 6 . The coefficient for the uninteracted labor supply term shows that increasing the private-sector labor force has a small and statistically insignificant impact on wages in the state sector (estimates of $\hat{\pi}_{1}$ in column 1). This coefficient is statistically insignificant. The interaction term (estimates of $\hat{\pi}_{2}$ in column 1 ) shows that there is a much larger negative effect on wages in the private sector. It is statistically significant at the $5 \%$ level. The joint estimate of $\hat{\pi}_{1}+\hat{\pi}_{2}$ (shown at the bottom of the table) is negative and shows that increasing private-sector labor supply by $1 \%$ reduces private-sector wages by $0.30 \%$, implying a private-sector labor demand elasticity of 3.38 . The joint estimate is statistically significant at the $10 \%$ level of significance $(p$-value $=0.072)$.

In columns (2)-(5), we gradually add controls for macroeconomic conditions that were discussed earlier used before: provincial GDP growth, provincial state-sector employment growth, pre-reform city income interacted with year fixed effects and differential trends for coastal and interior provinces. We see that the estimated interaction effect $\hat{\pi}_{2}$ is very stable across all of these specifications and always statistically

\footnotetext{
${ }^{24}$ The F-statistics for the first stage regressions are large, greater than 10 in most cases even after adjusting for within-city correlation in standard errors. Note that these first stage coefficients remain stable and statistically significant even after controlling for a variety of other macroeconomic trends, including the share of migrant workers in the city population (Table A.3, columns 2-5). We also present the reduced form estimates for the analogous specifications in Appendix Table A.4.
} 
significant, while the estimates of $\hat{\pi}_{1}$ are never distinguishable from zero. The magnitude of the joint estimates is also extremely stable across the specifications, and suggests that increasing private-sector labor supply by $1 \%$ can reduce private-sector wages by $0.23-0.32 \%$, implying a labor demand elasticity in the range 3.1-4.4.

The main concern for these estimates is that state-sector workers are not paid their marginal product and if state workers are paid more after the housing reform (e.g., because they now receive lower housing subsidies), then the interaction effect (which measures the change in the difference between private- and state-sector wages) may be driven spuriously by changes in state-sector pay. We believe that this is unlikely for several reasons. First, as we will show later, the wage residuals for statesector workers experience little change after the housing reform. Second, the main measurement problem with state-sector wages is the exclusion of non-wage benefits such as housing subsidies. If these are added to the pre-reform state-sector wage, then the decline in state-sector wage will be smaller than what it appears in the data such that our estimates are likely to be attenuated. In any case, we can address this directly by imputing the amount of housing subsidies for state-sector workers and adding it to the wages of state-sector workers for the pre-reform period. ${ }^{25}$ Column (6) shows that this makes little difference to our estimates.

Another concern for interpreting our estimates is the undercounting of migrant workers in our household survey. Since almost all migrant workers are employed by private enterprises, our data will understate the contribution of private enterprises to total urban employment. Moreover, if migrants are attracted to cities that have

\footnotetext{
${ }^{25}$ To impute the housing subsidies, we use data on rent and the quality of housing (e.g., total area, total living area, amenities, city and year fixed effects) for private-sector workers that rent housing from private owners and data on the quality of housing from pre-reform state-sector workers to predict the market value of the rent for these workers. Then, we subtract the actual value from the market value to estimate the state subsidy, and add the subsidy to the earnings of pre-reform state-sector workers. These variables are reported by the UHIES and the estimates are available upon request.
} 
implemented housing reforms because it is easier to obtain housing in those cities, then our estimates of the effect of the housing reform on private-sector employment will understate the true effect. The best approximation of migration during this period suggests that rural migrants increased from approximately 30 million in 1989 to 113 million in 2005 (Zhan, 2005).

We address this potential bias by obtaining data on the fraction of migrants (as a share of the total urban workforce) for the cities in our sample, and recalculating the private-sector labor supply to include migrant workers, with the assumption that all of these migrant workers are employed by the private sector. ${ }^{26}$ In our data, the share of migrants in the total urban workforce increased from about 9\% in 1990 to about $23 \%$ in 2005 . Column (7) shows that the 2SLS estimates using this adjusted private-sector labor supply variable are very close to the baseline in column (1). Thus, we believe that our estimates are unlikely to be biased by the exclusion of illegal migrants.

\subsection{Caveats}

We re-state the caveats for interpreting the labor demand elasticity estimates. First, recall from Section 3 that we assume that other factors of production in the private sector do not adjust to the increase in labor. While this is plausible in the short run, it is unlikely to be be true in the long run. Since improvements in capital and technology mitigates the negative effect of labor supply on wages, the elasticity estimates we obtain are larger in magnitude than the actual short-run elasticities.

\footnotetext{
${ }^{26}$ We obtained data on city-wise numbers of migrant worker from the $1 \%$ sample of the 1990 and 2000 censuses and the $20 \%$ sample of the $1 \%$ population survey of 2005 ; values are interpolated for intervening years. Given that almost none of the migrant workers worked in the state sector or enjoyed any housing benefits, the housing reform should have no effect on the migrant workers' labor supply i.e. the changes in labor supply which we use to identify labor demand elasticities are not going to be affected by the inclusion of migrant workers. Several papers have also documented the existence of labor market segregation and that migrant workers often do not have access to the same opportunities as those with urban hukou (Meng, 2012; Meng and Zhang, 2016).
} 
As such, they should be interpreted as the average of elasticities in the short and medium term.

Second, our data reports total labor income rather than hourly wages. Thus, interpreting our estimates assumes that the housing reform did not change the number of hours worked in the private sector.

Finally, interpreting $1 /\left(\hat{\pi}_{1}+\hat{\pi}_{2}\right)$ as the private-sector labor demand elasticity assumes that both private- and state-sector workers are paid wages that equal their marginal product. In particular, the fact that our estimates for the effect of the private-sector labor supply on state-sector wages is negative (albeit statistically insignificant) is consistent with the idea that state-sector workers are not paid their marginal products. This means that $\hat{\pi}_{1}+\hat{\pi}_{2}$ may overstate the impact of privatesector labor supply on private-sector wages and thus understate private-sector labor demand i.e. the private sector can absorb more labor than our estimates imply.

Since any correction of the state-sector wage data would involve a large number of ad hoc assumptions, and our estimates of $\hat{\pi}_{1}$ are statistically indistinguishable from zero, we do not attempt to correct state-sector wages. Instead, we take the more straightforward alternative and construct an estimate for labor demand elasticity for the private sector that is based only on $\hat{\pi}_{2}$. This alternative estimate is shown at the bottom of Table 6 and implies that a 1\% increase in private-sector labor supply reduces private-sector wages by $0.18-0.22 \%$, implying elasticity estimates of 4.6-5.5, which are somewhat larger than the previous set of estimates.

Both our original estimates and the alternative ones suggest that the privatesector labor demand is very elastic. Since the share of labor in the Cobb Douglas production function is $1-\alpha$, it also follows from our estimates that the implied labor share in the private sector is approximate 0.78 to 0.82 . The fact that this is higher than the standard assumption of 0.66 (i.e., two-thirds) is consistent with the belief 
that there is too much labor in the private sector, i.e. private-sector firms in China are under-capitalized.

\subsection{Implications for Private-Sector Wage Growth}

We find evidence to suggest that the increase in labor mobility after the housing reform equalized wages across the state and private sectors. Figure 4 shows the average wage residuals (wages demeaned by an individual's age, sex, her years of educational attainment and city fixed effects) for private- and state-sector workers against the number of years since the housing reform. Prior to the housing reform, private-sector workers earned higher wage residuals than public sector workers. However, the private-sector wage residuals declined to the same level as the state sector almost immediately following the reform and stayed at the same level afterwards. ${ }^{27}$ This suggests that prior to the reform, there were rents from working in the private sector, and these rents dissipated after the reform. An alternative explanation could be that this differential reflects the value of the in-kind housing benefits provided by the state sector, which the private sector has to compensate with wages. However, our results are unchanged if we add imputed rent subsidies to pre-reform state-sector wages. ${ }^{28}$

We can use our estimates of labor demand elasticity to shed light on the privatesector wages that are implied by the projected changes in Chinese urban labor supply. For example, if state-sector firms continue to downsize and lay off workers at the same rate as during the 1990s, then half of current state workers will move into the private sector in the next decade and the labor supply in that sector will triple

\footnotetext{
${ }^{27}$ Note that we can examine fewer pre-reform years for wages than for housing and employment because wage data begin to be reported later than the other variables.

${ }^{28}$ It is possible that rent subsidies are badly measured in our data and that there may have been other in-kind compensation in the state sector as well. We note that our result is consistent with Wang (2012)'s finding that workers who shifted into self-employment later experienced lower wage gains.
} 
in size. ${ }^{29}$ Taken literally and assuming that capital accumulation and technology improvements continue at the same rate as in our sample, our estimates imply that this will result in a 36-44\% reduction in average private-sector wages (using our most conservative estimates). Alternatively, consider the fact that if China continues to urbanize at the current rate, the urban population share will increase from approximately 50 to $58 \%$ in the next ten years. ${ }^{30}$ If all of the new urban workers work in the private sector, the the private-sector labor supply will quadruple in size (even if there is no change in the occupations of existing non-migrant urban workers), which will reduce urban private-sector wages by $54-66 \%$.

For the reasons discussed in Section 6.2, these back-of-the-envelope calculations should be interpreted very cautiously. In addition, note that these projected increases in labor supply are beyond the range in our sample data, and our estimates focus on voluntary movements to the private sector, which might decrease as private-sector wages converge to state-sector wages. In the latter case, large involuntary shifts to the private sector might result in even bigger wage declines than we estimate. These calculations only make the qualitative point that rapid labor force movements can significantly reduce private-sector wages, despite our finding an elastic private-sector labor demand. We discuss this more in the conclusion.

\section{Conclusion}

The goal of this study is to make progress on two questions. What are effective policies for gradually transitioning labor into the private sector? What is the labor demand elasticity in the new private sector during economic transition? Using the

\footnotetext{
${ }^{29}$ In our data, the share of non-migrant urban workers in the private sector grew from zero to $9 \%$ of the urban labor force between 1986 to 2005, which implies an approximate annual growth rate of $11-12 \%$ for the private-sector labor force.

${ }^{30}$ For example, World Bank (2012) projects that the current rate of urbanization will cause urban population share to increase from $50 \%$ in 2009 to $67 \%$ in 2030.
} 
staggered timing of the Chinese urban housing reform, we show that untying housing benefits from state-sector employment accounts for $30 \%$ of the increase in privatesector employment in Chinese cities during 1986-2005. By exploiting the plausibly exogenous variation in sector-specific labor supply induced by the urban housing reforms, we find that increasing private-sector labor supply by $10 \%$ reduces wages by 1.8 to $3.2 \%$; the implied labor demand elasticities range from 3.1 to 5.5 .

Our results have several interesting implications. First, finding an elastic labor demand implies that capital and technology are quite mobile across sectors in urban China. Second and more importantly, it suggests that the private sector, even in its infancy, can absorb a significant amount of labor without large wage declines. However, the projected magnitudes of labor movement into the Chinese private sector are so large that they still imply drastic private-sector wage reductions, if capital and technology movements remain at the same rate as in our data. Thus, to minimize wage reductions, Chinese policy makers may want to consider policies that increase the mobility of other factors of production into the private sector.

Finally, the evidence that increasing labor mobility reduces rents earned by private-sector workers suggests that transition may be very unpopular with certain segments of the population despite its potential welfare benefits. This is important for policy makers to take into account from a political economy perspective.

In extrapolating our results to other contexts, it is important to note that the magnitude of the estimates are specific to the context of this study. In particular, relative to other transitioning economies, China experienced little political and social upheaval and steady economic growth. Nevertheless, the insights that reducing benefits tied to state-sector employment is an effective policy for gradually releasing workers from the state sector, that large movements into the private sector should ideally be accompanied by policies that facilitate the movement of other factors of 
production and that increased mobility can dissipate rents for workers initially in the private sector are generalizable.

Our study has two important implications for future research on economic transition. First, the results suggest that understanding the determinants and the speed of the flow of the factors of production into the private sector is an important avenue for future research. Second, and more generally, most past empirical studies of economic transition have been descriptive or focused on cross-country comparisons. Our study provides an example of how policy experiments and newly available micro-data from transitioning economies can be used to provide well-identified estimates and enhance our understanding of the transition process. 


\section{References}

Acemoglu, Daron, David H. Autor, and David Lyle, "Women, War, and Wages: The Effect of Female Labor Supply on the Wage Structure at Mid-century," Journal of Political Economy, June 2004, 112 (3), 497-551.

Aghion, Philippe and Olivier Jean Blanchard, "On the Speed of Transition Central Europe," NBER Working Papers 4736, National Bureau of Economic Research May 1994.

_, _, Wendy Carlin, and Centre for Economic Policy Research (Great Britain), The Economics of Enterprise Restructuring in Central and Eastern Europe Discussion paper, Centre for Economic Policy Research, 1994.

Aghion, Phillipe, "Economic Reform in Eastern Europe: Can Theory Help?," European Economic Review, 1993, 37, 525-532.

Angrist, Joshua, "Short-Run Demand for Palestinian Labor," Journal of Labor Economics, July 1996, 14 (3), 425-53.

Bai, Chong-En, David D. Li, Yingyi Qian, and Yijiang Wang, "Limiting Government Predation Through Anonymous Banking: A Theory with Evidence from China," William Davidson Institute Working Papers Series 275, William Davidson Institute at the University of Michigan July 1999.

_, _, Zhigang Tao, and Yijiang Wang, "A Multi-Task Theory of the State Enterprise Reform," William Davidson Institute Working Papers Series 367, William Davidson Institute at the University of Michigan 2001.

_ , Jiangyong Lu, and Zhigang Tao, "The Multitask Theory of State Enterprise Reform: Empirical Evidence from China," American Economic Review, May 2006, $96(2), 353-357$.

_ , _ , and _ , "How Does Privatization Work in China?," Journal of Comparative Economics, September 2009, 37 (3), 453-470.

Barnett, Steven, Jeffrey M. Davis, Rolando Ossowski, and Thomas J. Richardson, "Fiscal and Macroeconomic Impact of Privatization," IMF Occasional Papers 194, International Monetary Fund June 2000.

Berkowitz, Daniel and David DeJong, "Entrepreneurship and Post-Socialist Growth," William Davidson Institute Working Papers Series 406, William Davidson Institute at the University of Michigan October 2001.

Bilsen, Valentijn and Jozef Konings, "Job Creation, Job Destruction, and Growth of Newly Established, Privatized, and State-Owned Enterprises in Transition Economies: Survey Evidence from Bulgaria, Hungary, and Romania," Journal of Comparative Economics, September 1998 , 26 (3), 429-445. 
Cameron, A. Colin, Jonah B. Gelbach, and Douglas L. Miller, "BootstrapBased Improvements for Inference with Clustered Errors," The Review of Economics and Statistics, August 2008, 90 (3), 414-427.

Card, David, "The Impact of the Mariel Boatlift on the Miami Labor Market," Industrial and Labor Relations Review, 1990, 43 (2), pp. 245-257.

Denisova, Irina, Markus Eller, Tomothy Frye, and Ekaterina Zhuravskaya, "Who Wants to Revise Privatization? The Complementarity of Market Skills and Institutions," American Political Science Review, 2009, (2), 284-304.

Duda, Mark, Xiulan Zhang, and Mingzhu Dong, "China's Home-ownershiporiented Housing Policy: An Examination of Two Programs Using Survey Data from Beijing," Harvard University Joint Center for Housing Studies Working Paper W05-7, 2005.

Faggio, Giulia and Jozef Konings, "Gross Job Flows and Firm Growth in Transition Countries: Evidence Using Firm Level Data on Five Countries," CEPR Discussion Papers 2261, Center for Economic and Policy Research October 1999.

Feng, Shuaizhang, Yingyao Hu, and Robert Moffitt, "Long Run Trends In Unemployment And Labor Force Participation In China," NBER Working Papers 21460, National Bureau of Economic Research 2015.

Fernandez, Raquel and Dani Rodrik, "Resistance to Reform: Status Quo Bias in the Presence of Individual- Specific Uncertainty," The American Economic Review, 1991, 81 (5), pp. 1146-1155.

Giles, John, Albert Park, and Fang Cai, "How Has Economic Restructuring Affected China's Urban Workers," China Quarterly, 2006, 181, 61-95.

Gruber, Jonathan and Brigitte C. Madrian, "Health Insurance, Labor Supply, and Job Mobility: A Critical Review of the Literature," NBER Working Papers 8817, National Bureau of Economic Research February 2002.

Guriev, Sergei and William Megginson, "Privatization: What Have We Learned?," in Francois Bourguignon and Boris Pleskovic, eds., Beyond Transition, Washington D.C.: ABCDE World Bank, 1997.

Huang, Yasheng, Selling China: Foreign Direct Investment During the Reform Era Cambridge modern China series, Cambridge, U.K.: Cambridge University Press, 2003.

Kikeri, S., "Privatization and Labour. What Happens to Workers When Governments Divest?," Technical Report 1998. 
Lin, Justin Yifu, "Rural Reforms and Agricultural Growth in China," American Economic Review, March 1992, 82 (1), 34-51.

McMillan, John and Christopher Woodruff, "Entrepreneurs in Economic Reform," Working Paper 102, Center for Research on Economic Development and Policy Reform 2001.

_ and _ , "The Central Role of Entrepreneurs in Transition Economies," Journal of Economic Perspectives, Summer 2002, 16 (3), 153-170.

Megginson, William L. and Jeffry M. Netter, "From State to Market: A Survey of Empirical Studies on Privatization," Journal of Economic Literature, 2001, 39 (2), 321-389.

Meng, Xin, Labour Market Reform in China, Cambridge U.K.: Cambridge University Press, 2000.

_ , "Labor Market Outcomes and Reforms in China," Journal of Economic Perspectives, 2012, 26 (4), 75-102.

- and Dandan Zhang, "Large Scale Internal Migration on Wages of Urban 'Native' Workers in China: 1990 to 2010," Working Paper, 2016.

Mitra, P., M. Selowsky, and World Bank, Transition-the First Ten Years: Analysis and Lessons for Eastern Europe and the Former Soviet Union Other World Bank Bks, The World Bank, 2002.

Pan, Guangjun, "Background Article: the Process of the Chinese Housing Reform (in Chinese)," Chinese Reform, 2000, 11, 15-19.

Poncet, Sandra, "A Fragmented China: Measure and Determinants of Chinese Domestic Market Disintegration," Review of International Economics, 2005, 13 (3), 409-430.

Roland, Gerard, "On the Speed and Sequencing of Privatisation and Restructuring," Economic Journal, September 1994, 104 (426), 1158-1168.

_ , "The Political Economy of Transition," Journal of Economic Perspectives, Winter 2002, 16 (1), 29-50.

Rutkowski, Jan J., Changes in the Wage Structure during Economic Transition in Central and Eastern Europe, Washington D.C.: The World Bank Press, 1996.

Shleifer, Andrei, A Normal Country: Russia After Communism, Harvard University Press, 2005. 
Svejnar, Jan, "Labor Markets in the Transitional Central and East European Economies," in O. Ashenfelter and D. Card, eds., Handbook of Labor Economics, Vol. 3 of Handbook of Labor Economics, Amsterdam: Elsevier, April 1999, chapter 42, pp. 2809-2857.

Wang, Shing-Yi, "Credit Constraints, Job Mobility, and Entrepreneurship: Evidence from a Property Reform in China," The Review of Economics and Statistics, May 2012, 94 (2), 532-551.

Wang, Yaping and Alan Murie, Housing Policy and Practice in China, New York: St. Martin's Press, 1999.

World Bank, "China 2030: Building a Modern, Harmonious, and Creative HighIncome Society," World Bank Report, The World Bank and The Development Research Center of the State Council, the People's Republic of China 2012.

Yuan, Renbiao, "Chinese Housing Reform Memoir (in Chinese)," China Construction Daily, 2000.

Zhan, Shaohua, "Rural Labour Migration in China: Challenges for policies," Policy Paper 10, UNESCO 2005.

Zhuravskaya, Ekaterina, "Whither Russia? A Review of Andrei Shleifers A Normal Country," Journal of Economic Literature, March 2007, 45 (1), 127-146. 


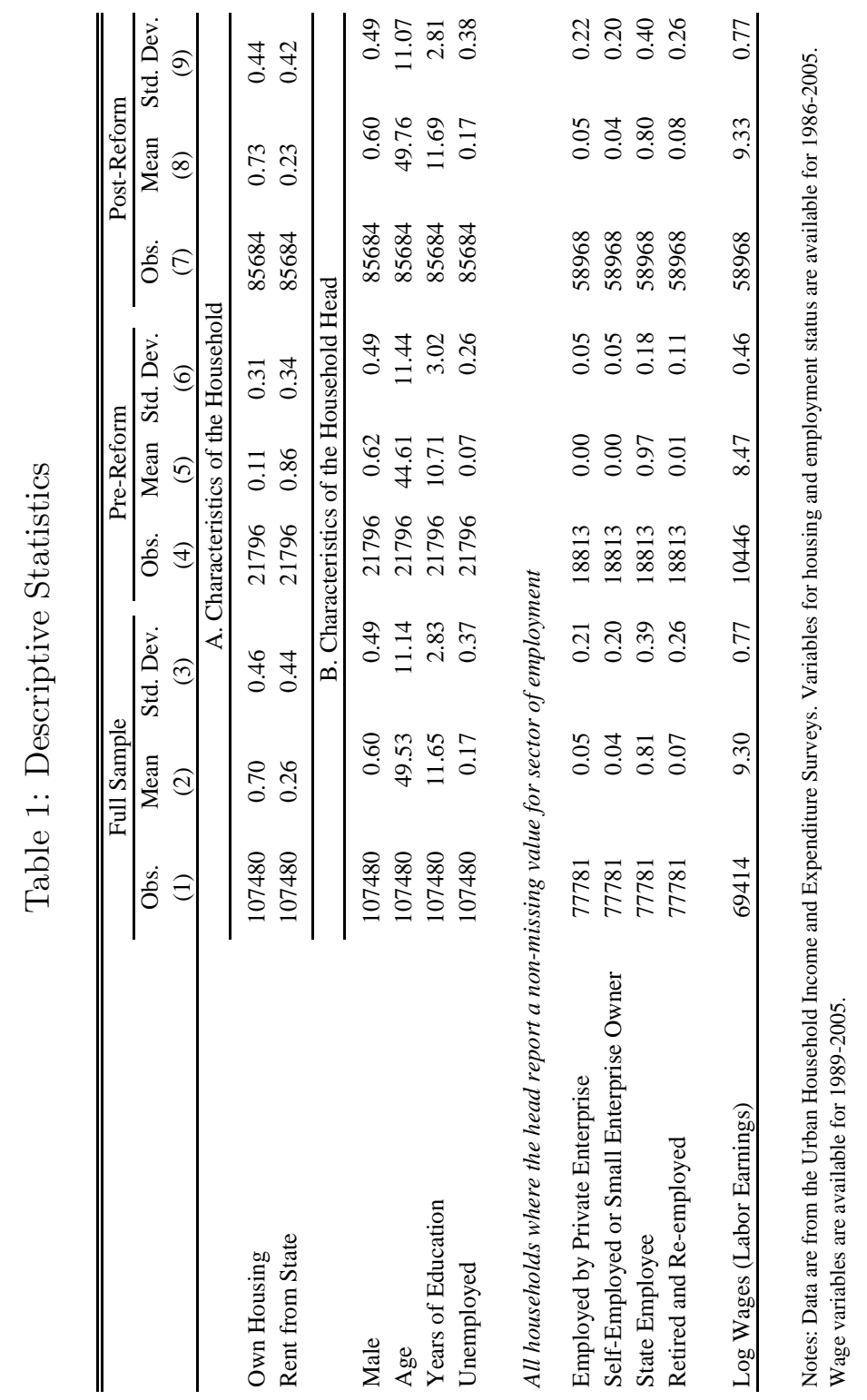




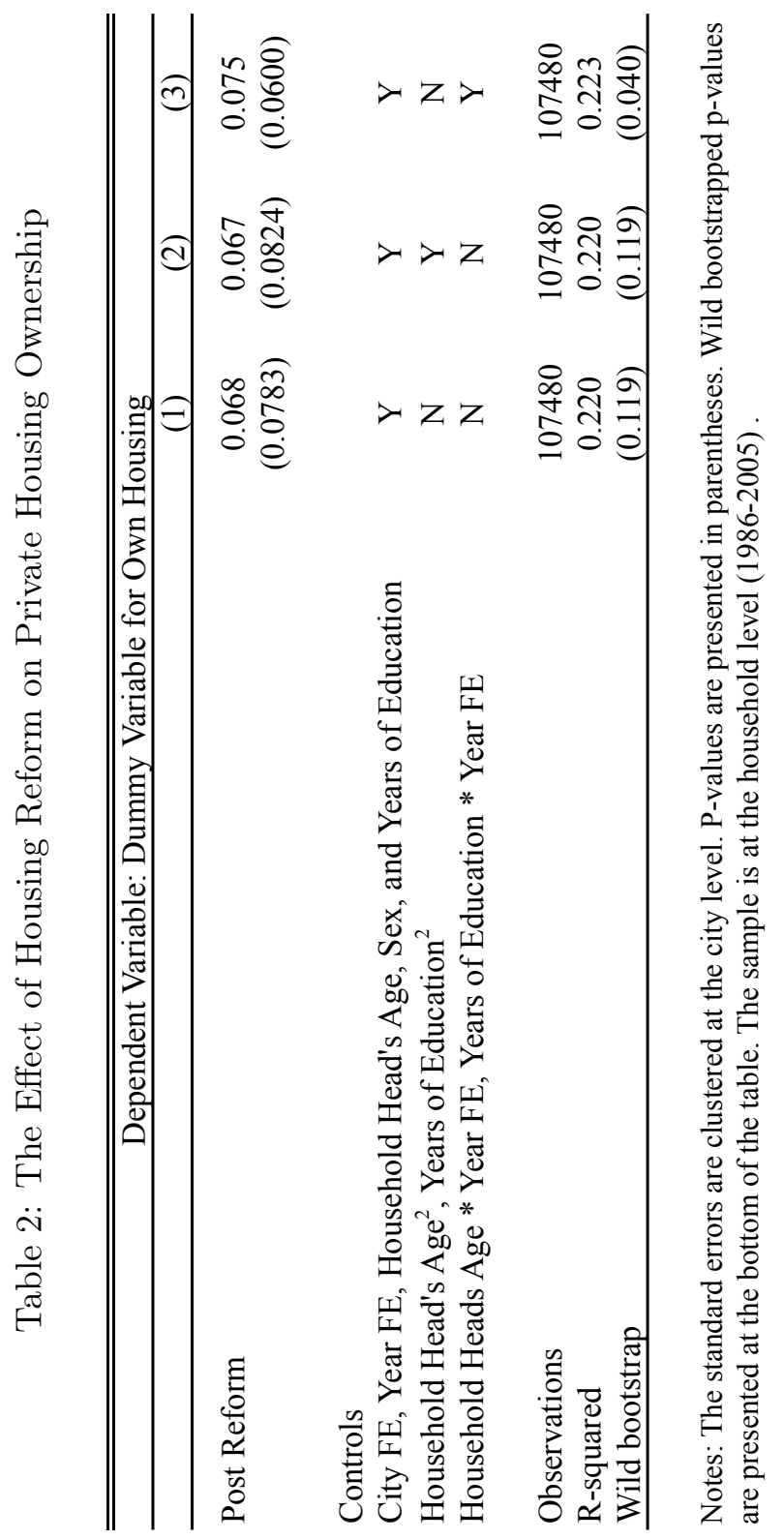




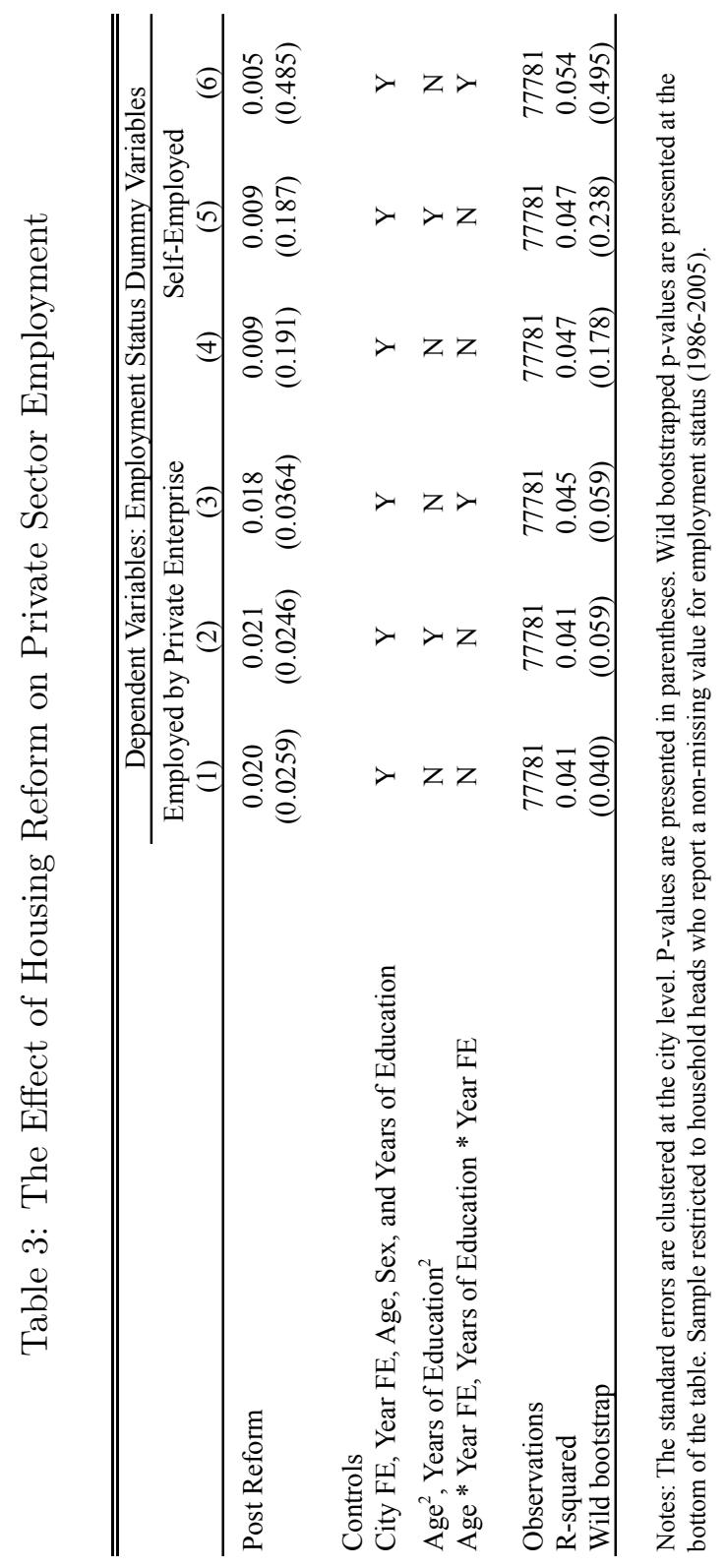




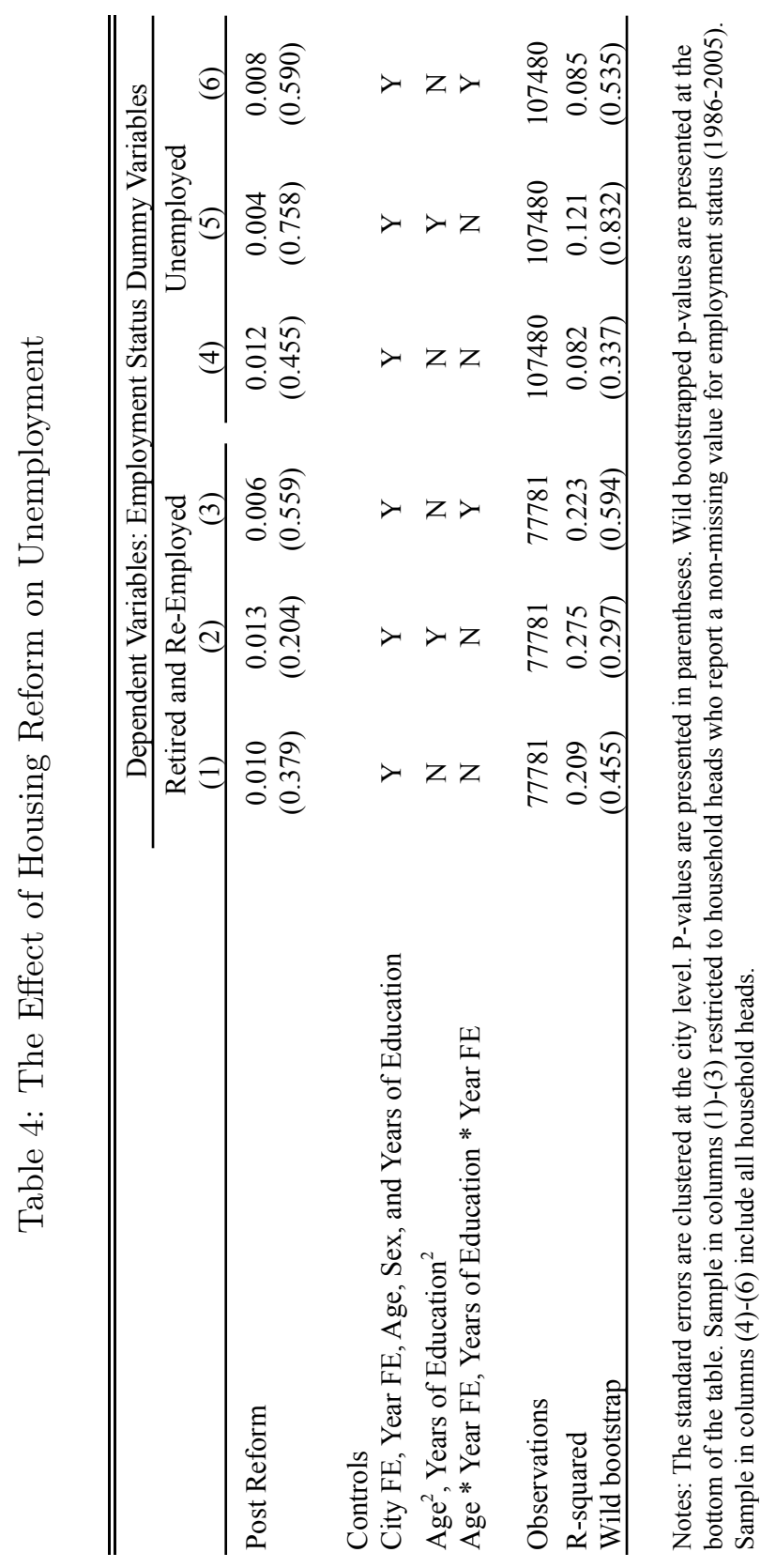




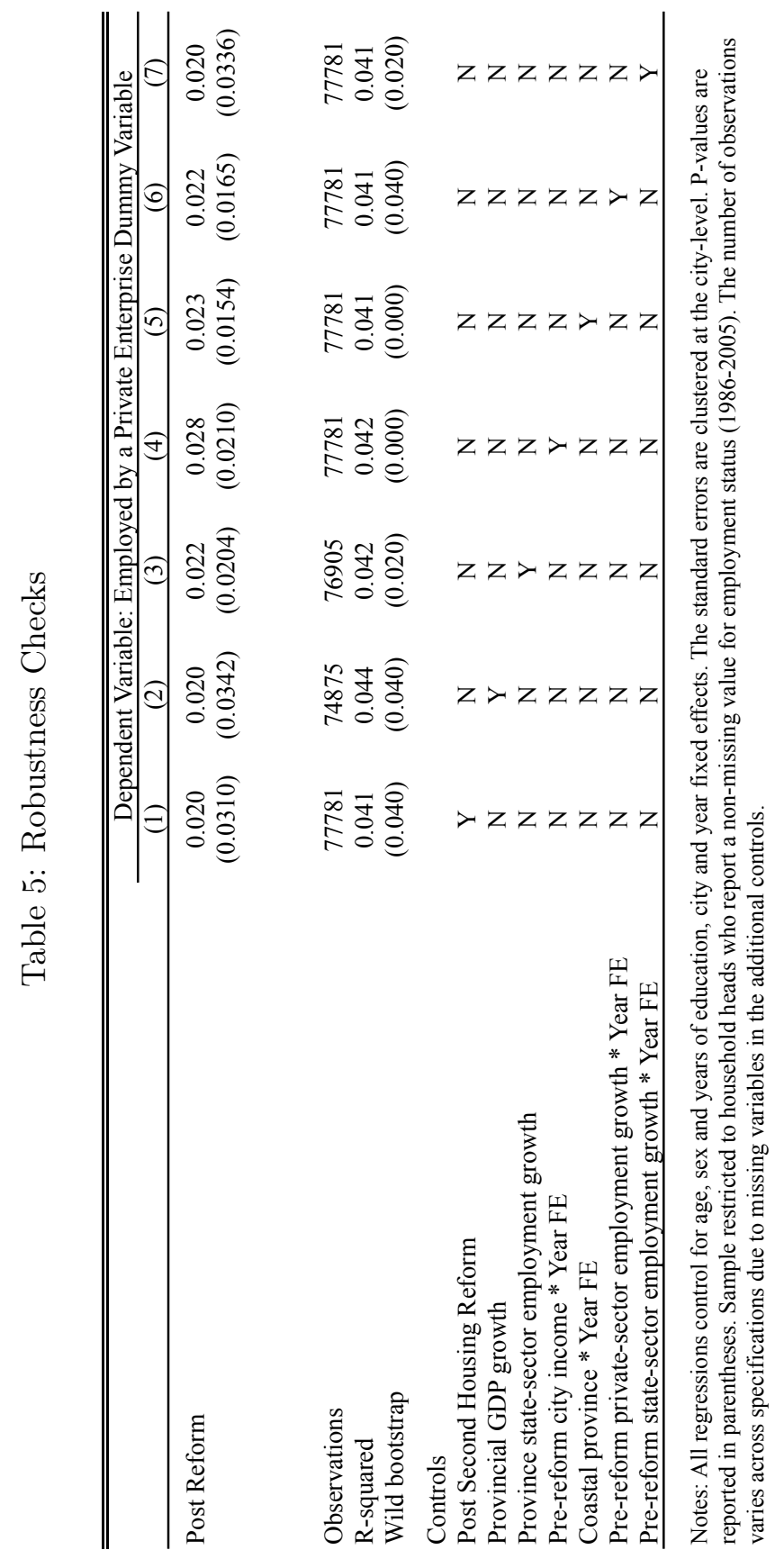




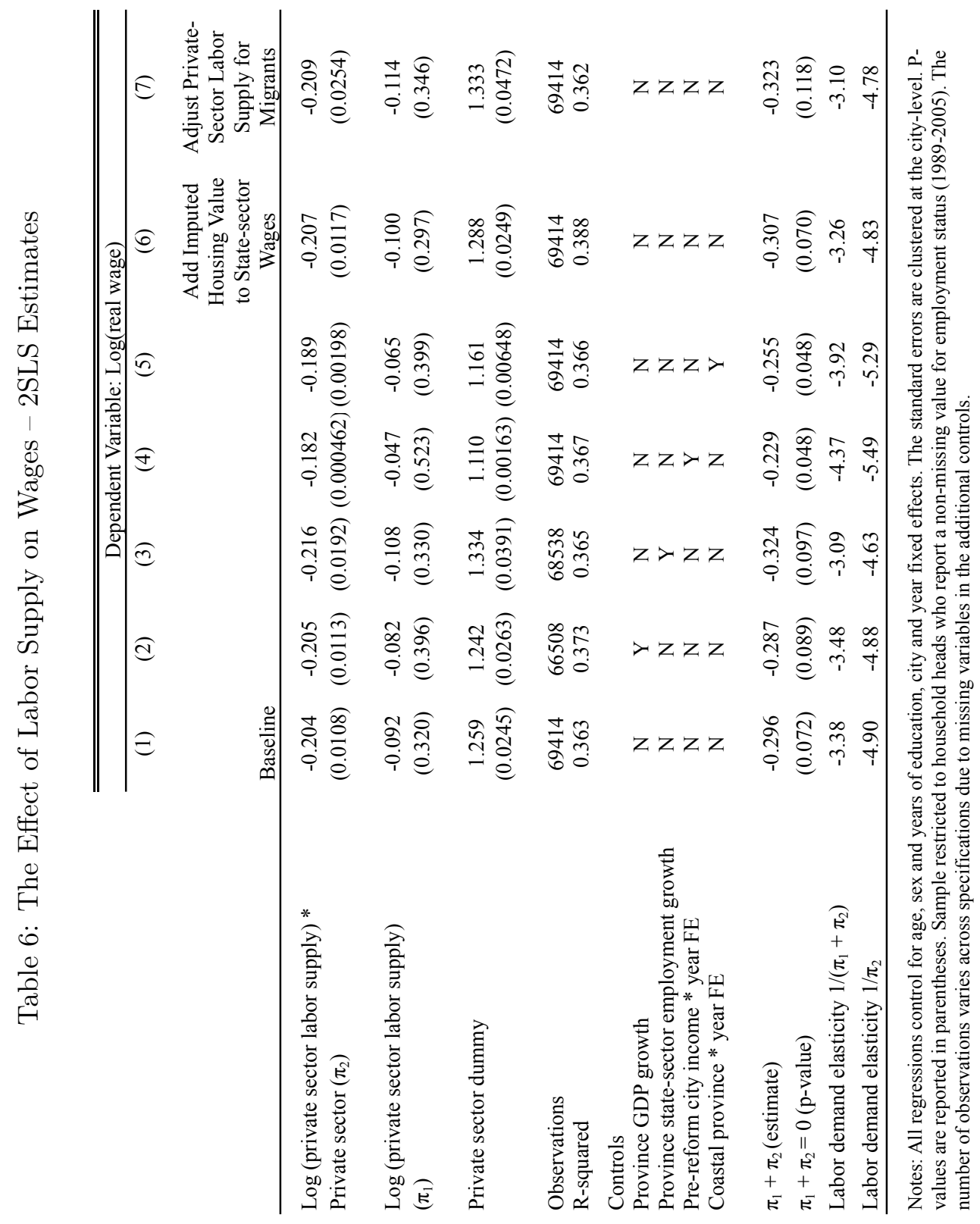


Figure 1: Private Housing Ownership

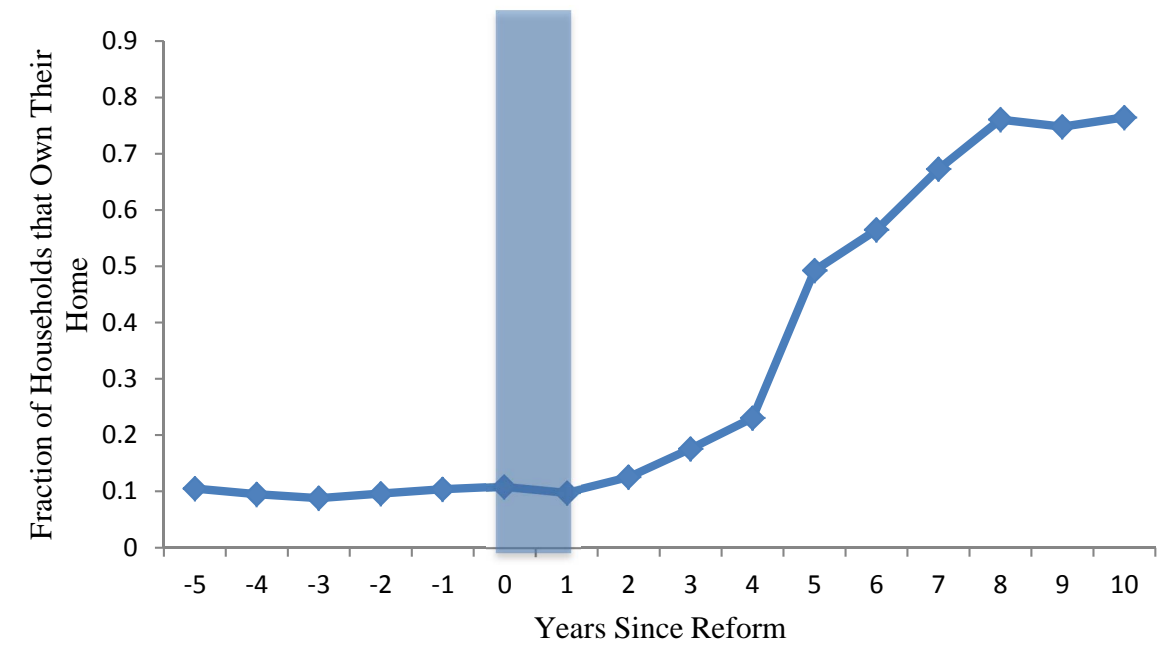


Figure 2: Employed by a Private Enterprise

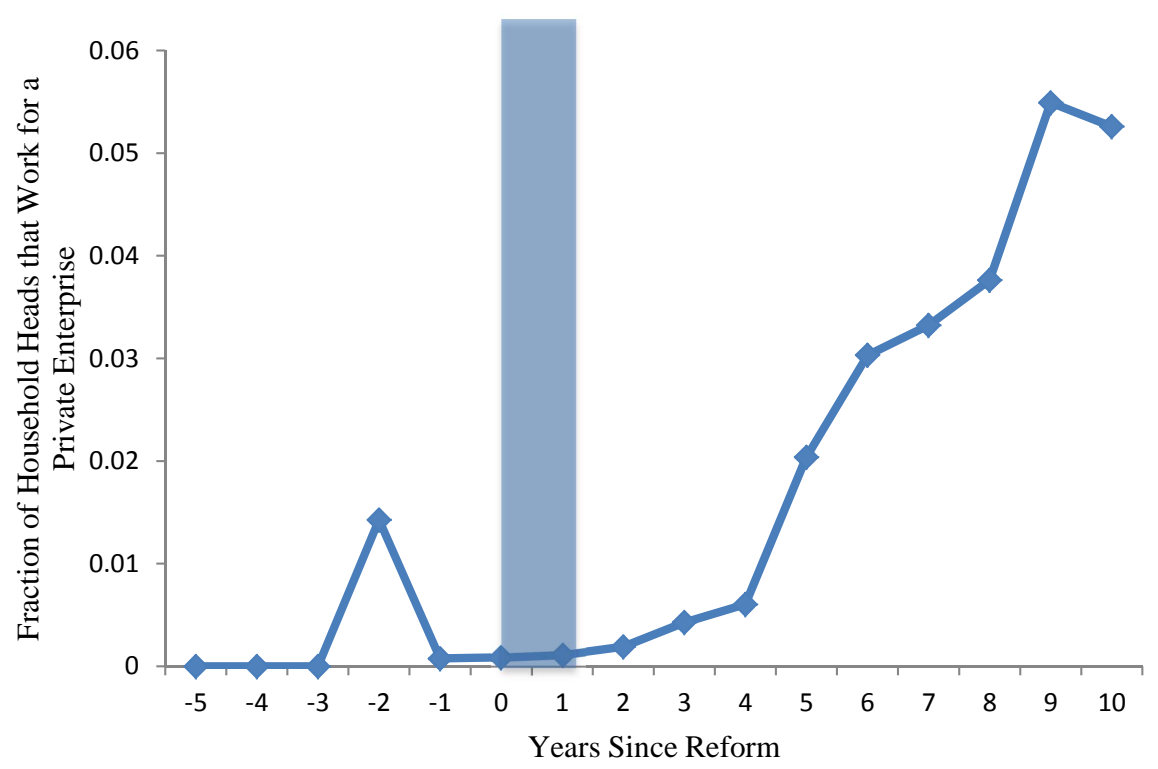

Figure 3: Self-Employed or Small Enterprise Owners

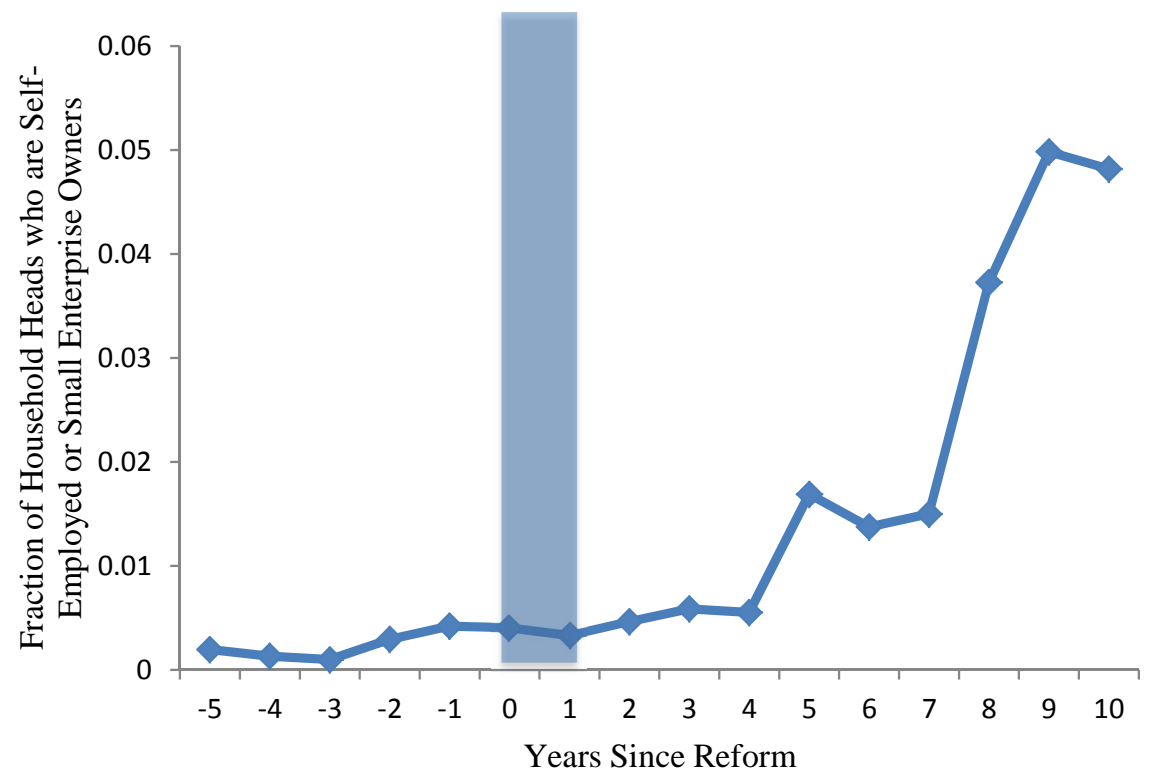


Figure 4: Private and State Sector Wage Residuals - Demeaned by individual characteristics and city fixed effects

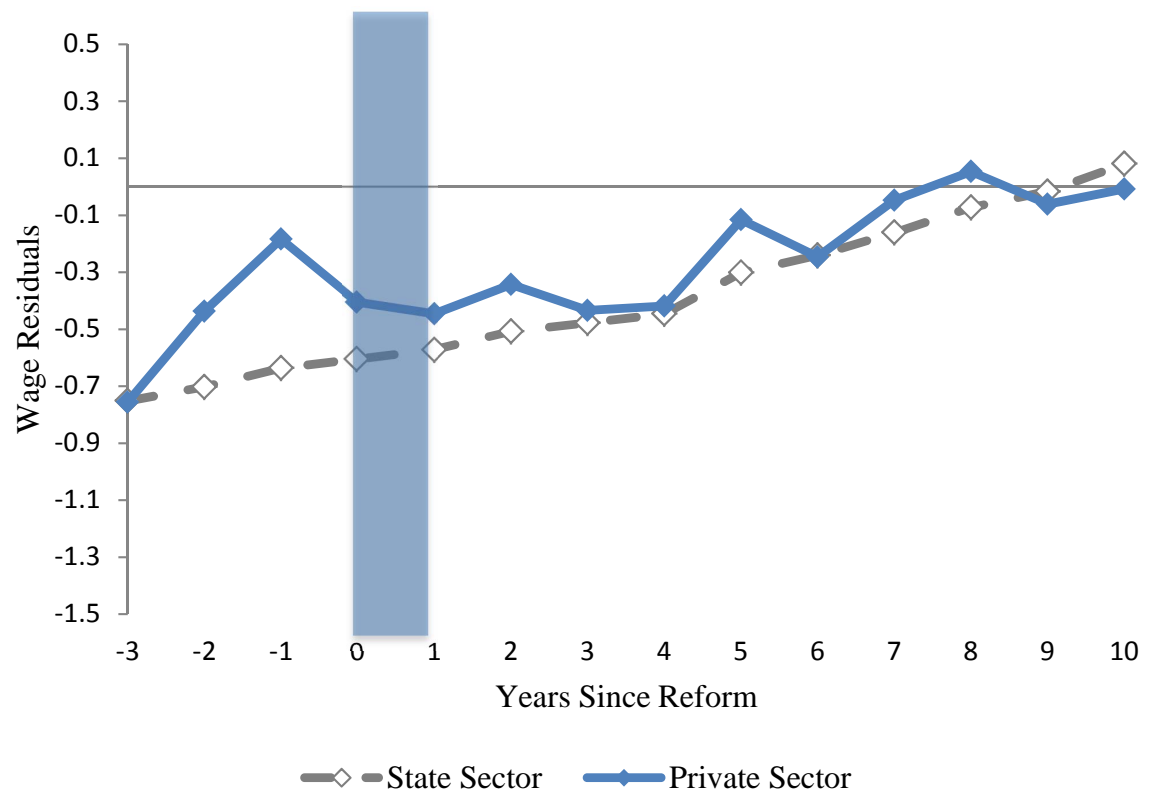


Table A.1: The Timing of the Reform

\begin{tabular}{cc}
\hline \hline Year of reform & \# cities \\
\hline 1988 & 3 \\
1989 & 1 \\
1990 & 2 \\
1991 & 2 \\
1992 & 10 \\
1993 & 6 \\
1994 & 1 \\
1995 & 1 \\
1997 & 1 \\
& \\
Total & 27 \\
\hline
\end{tabular}




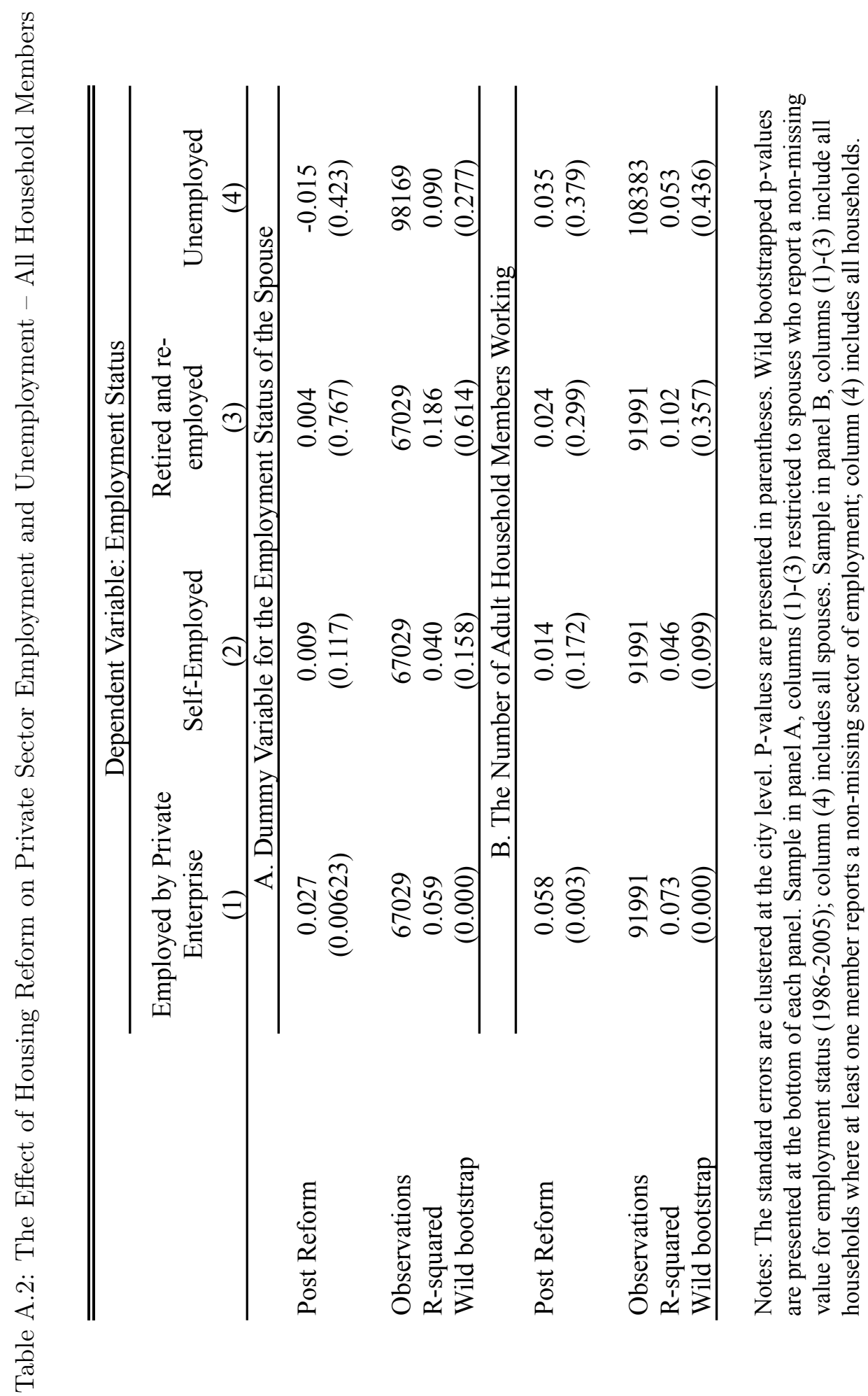




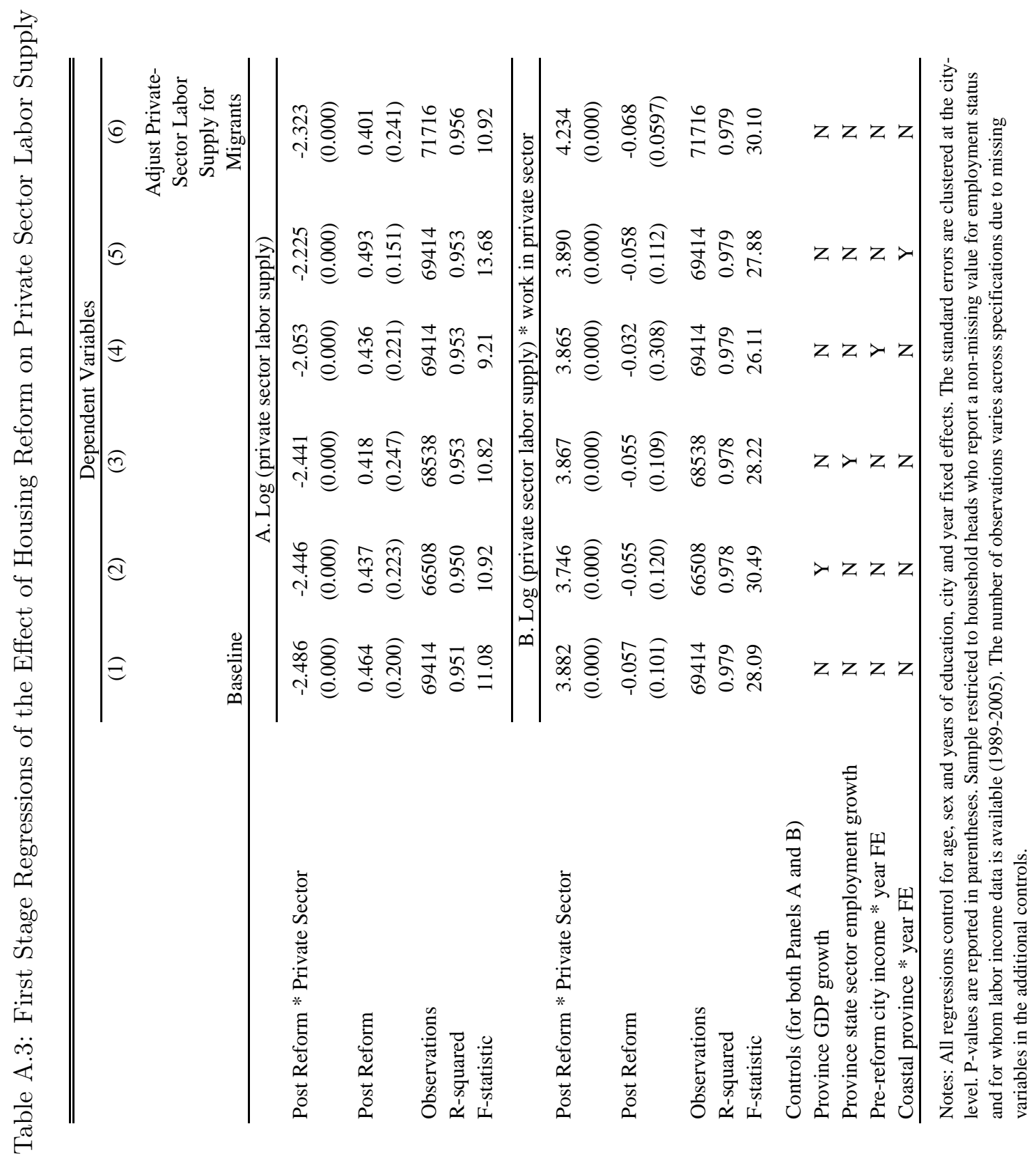




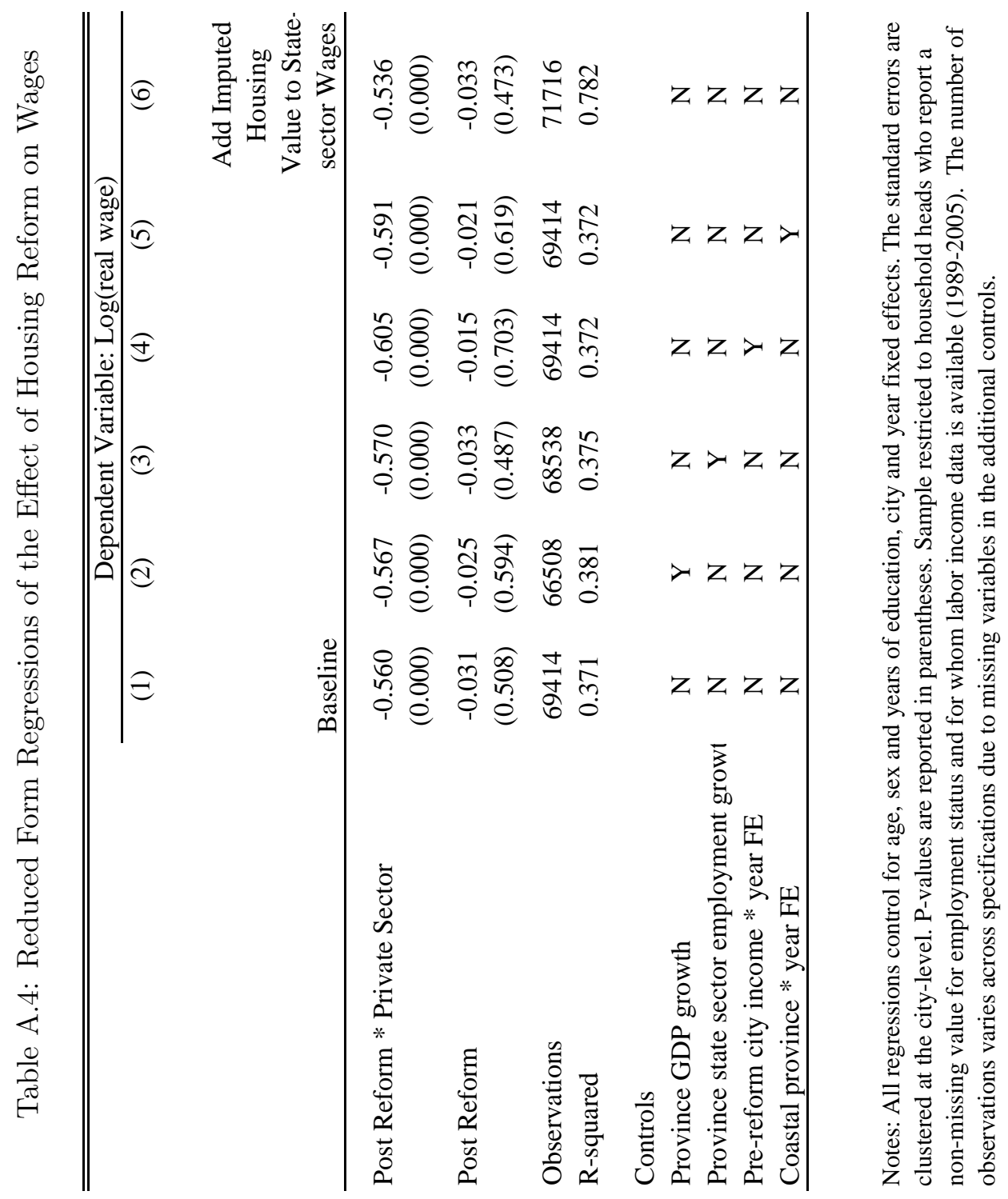

